\title{
Atmospheric carbon cycle dynamics over the ABoVE domain: an integrated analysis using aircraft observations (Arctic-CAP) and model simulations (GEOS)
}

Colm Sweeney $^{1}$, Abhishek Chatterjee ${ }^{2,3}$, Sonja Wolter ${ }^{4,1}$, Kathryn McKain ${ }^{4,1}$, Robert Bogue ${ }^{5 *}$, Tim

5 Newberger $^{4,1}$, Lei Hu ${ }^{4,1}$, Lesley Ott ${ }^{3}$, Benjamin Poulter ${ }^{3}$, Luke Schiferl ${ }^{6}$, Brad Weir ${ }^{2,3}$, Zhen Zhang ${ }^{7}$, Charles E. Miller ${ }^{5}$

${ }^{1}$ NOAA Earth System Research Laboratory, Boulder, CO, USA

${ }^{2}$ Universities Space Research Association, Columbia, MD, USA

${ }^{3}$ NASA Goddard Space Flight Center, Greenbelt MD, USA

$10{ }^{4}$ CIRES, University of Colorado, Boulder, CO, USA

${ }^{5}$ Jet Propulsion Laboratory, California Institute of Technology, Pasadena CA, USA

${ }^{6}$ LDEO, Columbia University, New York, NY, USA

${ }^{7}$ University of Maryland, College Park, MD, USA

* now at McGill University, Montreal, QC, Canada

15 Correspondence to: Colm Sweeney (colm.sweeney@noaa.gov)

\begin{abstract}
The Arctic Carbon Atmospheric Profiles (Arctic-CAP) project conducted six airborne surveys of Alaska and northwestern Canada between April and November 2017 to capture the spatial and temporal gradients of northern high-latitude carbon dioxide $\left(\mathrm{CO}_{2}\right)$, methane $\left(\mathrm{CH}_{4}\right)$ and carbon monoxide (CO) as part of NASA's Arctic-Boreal Vulnerability Experiment (ABoVE). The Arctic-CAP sampling strategy involved acquiring vertical profiles of $\mathrm{CO}_{2}, \mathrm{CH}_{4}$ and $\mathrm{CO}$ from the surface to $5 \mathrm{~km}$ altitude at 25 sites around the ABoVE domain on a 4- to 6-week time interval. We observed vertical gradients of $\mathrm{CO}_{2}, \mathrm{CH}_{4}$ and $\mathrm{CO}$ that vary by eco-region and duration of the sampling period, which spanned the majority of the seasonal cycle. All Arctic-CAP measurements were compared to a global simulation using the Goddard Earth Observing System (GEOS) modeling system. Comparisons with

25 GEOS simulations of atmospheric $\mathrm{CO}_{2}, \mathrm{CH}_{4}$ and $\mathrm{CO}$ highlight the potential of these multi-species observations to inform improvements in surface flux estimates and the representation of atmospheric transport. GEOS simulations provide estimates of the near surface average $\mathrm{CO}_{2}$ and $\mathrm{CH}_{4}$ enhancements that are well correlated with aircraft observations ( $\mathrm{R}=0.74$ and $\mathrm{R}=0.60$ respectively), suggesting that GEOS has reasonable fidelity over this complex and heterogeneous region. This model-data comparison over the ABoVE domain reveals that while current state-of-the-art models and flux estimates are able to capture broadscale spatial and temporal patterns in near-surface $\mathrm{CO}_{2}$ and $\mathrm{CH}_{4}$ concentrations, more work is needed to resolve fine-scale flux features that are observed. The study also provides a framework for benchmarking a global model at regional scales, which is needed to use climate models as tools to investigate high-latitude carbon-climate feedbacks.
\end{abstract}




\section{Introduction}

Accelerated Arctic system change (Hinzman et al., 2013), coupled with the vast quantities of carbon sequestered in the permafrost soils of the northern high latitudes (Hugelius et al., 2014), have led to concerns about the potential for significant carbon emissions due to changes in ecosystems, permafrost and large-scale disturbances like fires (Schuur et al., 2015; McGuire et al., 2018; Turetsky et al., 2020). Our understanding of the magnitude and behavior of the carbon system response to these changes is rudimentary (Koven et al., 2015). For instance, release of carbon from the permafrost pool could result in increased emissions of $\mathrm{CH}_{4}$ from anaerobic degradation; increased emissions of $\mathrm{CO}_{2}$ from aerobic degradation; increased uptake of carbon due to new availability of nutrients and above-ground

45 ecosystem growth; or an increase in mobilization of carbon through runoff. Alternatively, increases in disturbances such as fires may significantly impact below-ground carbon storage, uptake of $\mathrm{CO}_{2}$ and emissions of $\mathrm{CH}_{4}, \mathrm{CO}$, and $\mathrm{CO}_{2}$. Limitations in our understanding of the accuracy of modeled fluxes of $\mathrm{CO}_{2}, \mathrm{CO}$ and $\mathrm{CH}_{4}$ have increased uncertainties in predictions of the magnitude of Arctic carbon-climate feedbacks (e.g., Koven et al., 2011; Lawrence et al., 2015; Schaefer et al., 2014; Schneider von

50 Deimling et al., 2012; Schuur et al., 2015).

The lack of observations represents a significant limitation that lead to both enhanced uncertainty and reduced fidelity in our model simulations. In general, land- and ocean-atmosphere fluxes from climate models are most commonly evaluated using flux measurements made with eddy covariance or flux chamber techniques. While flux measurements of these types are widely available over many ecosystem types, they represent the impact of limited spatial domains that are rarely more than a $1000 \mathrm{~m}$ radius around a given site (Gockede et al., 2005; Schmid, 2002) and may be significantly smaller depending on topography, wind direction and boundary layer stability. Land surface inhomogeneities within these small footprints (Baldocchi et al., 2005) and regional-scale (100-1000 km scales) variability of these ecosystems can lead to significant biases when eddy covariance measurements are scaled up to

60 represent large areas. This is especially true in the Arctic where microtopography can result in fluxes varying by orders of magnitude on a scale of 1-100 meters (Johnston et al., 2014). While flux towers can be found in many ecosystem types, they do not necessarily represent landscape-scale heterogeneity within a broadly defined ecosystem such as the boreal forest, peatlands, or tundra regions of the Arctic. An alternative to the "bottom-up" evaluation approach is the "top-down" approach, which makes use of

65 atmospheric measurements of species like $\mathrm{CO}_{2}, \mathrm{CH}_{4}$ and $\mathrm{CO}$ and modeled atmospheric transport patterns to infer the surface fluxes needed to reproduce observed atmospheric concentrations. This inverse approach generally takes a forward-flux model, or a set of observations that are likely correlated with the flux, as a prior or first guess. The inverse approach then estimates the flux by scaling the prior. While the inverse approach results in a flux estimate that meets the constraint of the trace gas

70 measurements and modeled transport, the variability in surface flux from these analyses cannot be directly attributed to mechanisms such as temperature changes, $\mathrm{CO}_{2}$ fertilization and water stress. Also, inverse methods are influenced by errors in atmospheric transport and assumptions about error covariances, which are difficult to characterize (Gourdji et al., 2012; Lauvaux et al., 2012; Mueller et al., 2018; Chatterjee and Michalak, 2013).

75 In this study, we explore a hybrid approach using atmospheric trace gas mole fractions from aircraft profiles and an advanced global tracer transport model to evaluate the ability of current state-of-the-art 
bottom-up land-surface flux models to capture complex carbon cycle dynamics over the northern highlatitudes. NASA's Goddard Earth Observing System (GEOS) general circulation model (GCM) is used with a unique combination of surface flux components for $\mathrm{CO}_{2}, \mathrm{CH}_{4}$ and $\mathrm{CO}$ to create $4 \mathrm{D}$ atmospheric Atmospheric Profiles (Arctic-CAP) airborne campaign.

Both the Arctic-CAP project and the GEOS model runs for the domain are part of NASA's Arctic Boreal Vulnerability Experiment (ABoVE, www.above.nasa.gov), a decade-long research program focused on evaluating the vulnerability and resiliency of the Arctic tundra and boreal ecosystems in

85 western North America (Miller et al., 2019). One of the primary objectives of the ABoVE program is to better understand the major processes driving observed trends in Arctic carbon cycle dynamics, in order to understand how the ecosystem is responding to environmental changes and to characterize the impact of climate feedbacks on greenhouse gas emissions. ABoVE has taken two approaches to better understand critical ecosystem processes vulnerable to change. The first is through ground-based surveys and monitoring sites in representative regions of the ABoVE domain. These multi-year studies provide a backbone for intensive investigations, such as airborne deployments. The Arctic-CAP campaign discussed here was one such airborne deployment that was conducted during the spring-summer-fall of 2017 (Section 2.1). The subsequent analysis described here illustrates how improvements in surface models develop through ground-based surveys, and monitoring sites can be evaluated and tested over

95 larger spatial scales using such aircraft profiles (Section 3). This study uses Arctic-CAP aircraft profiles to directly evaluate both the transport model and the terrestrial surface flux models of $\mathrm{CO}_{2}, \mathrm{CH}_{4}$ and $\mathrm{CO}$. For the sake of demonstration, we rely on one transport model and one flux scenario for each tracer (i.e., $\mathrm{CO}_{2}, \mathrm{CH}_{4}$ and $\mathrm{CO}$ ) to show the utility of the three carbon species to diagnose and identify deficiencies in both flux and transport models. Ongoing and future studies build upon the results discussed here and further diagnose transport and flux patterns from multiple models based on additional aircraft and ground-based observations throughout the ABoVE domain.

\section{Methods}

\subsubsection{Arctic-CAP Flight Planning and Sampling Strategy}

Arctic-CAP was designed to measure vertical profiles of atmospheric $\mathrm{CO}_{2}, \mathrm{CH}_{4}$ and $\mathrm{CO}$ mole fraction 105 to capture the spatial and temporal variability of carbon cycle dynamics (Parazoo et al., 2016; Sweeney et al., 2015) across the ABoVE domain. Flights were conducted aboard a Scientific Aviation Mooney Ovation 3 (N617DH). Six campaigns were performed during 2017: late April - early May, June, July, August, September, and late-October - early November. Arctic-CAP flights surveyed the ABoVE Study Area and were organized around an Alaskan circuit and a Canadian circuit (Fig. 1). The Alaskan circuit

110 covered a region where aircraft measurements were previously made during 2012-2015 by the Carbon in Arctic Reservoirs Vulnerability Experiment (CARVE; Miller et al., 2012), which included the Alaskan Boreal Interior, Brooks Range Tundra and the Alaskan Tundra ecoregions. The Arctic-CAP Alaska circuit was primarily west of Fairbanks, Alaska, and include Galena, Bethel, Unalakleet, Nome and Kotzebue. The northern section of the circuit overflew Utqiagvik (formerly Barrow), Atqasuk, 115 Deadhorse and the Toolik Lake Research Station - all North Slope tundra sites with long-term 
measurements of atmospheric $\mathrm{CO}_{2}$ and $\mathrm{CH}_{4}$. The Arctic-CAP Canadian circuit focused on flying over sites in and around the Inuvik and Yellowknife areas in the Canadian Arctic. In the Inuvik region, the aircraft overflew the Trail Valley Creek and Havipak Creek research sites, and the Daring Lake and Scotty Creek flux tower sites were overflown on the way to and from the Yellowknife area. The Canadian Circuit expands upon the ecoregions covered in the CARVE missions to include the Boreal Cordillera, Taiga Plain, Taiga Shield and the Southern Arctic Tundra ecoregions.

Approximately 25 vertical profiles were acquired during each campaign (Fig 2). The majority of each flight day was spent in the well-mixed boundary layer with 2-4 vertical profiles up to altitudes of 5000 $\mathrm{m}$ above sea level (masl). Using missed approaches to get as near to the ground as possible, profiles

125 diagnosed the temporal change in the boundary layer as well as the residual layers above where surface fluxes may have recently $(<3$ days) influenced that atmospheric column. During the 2017 season, Arctic-CAP flights were complemented by additional vertical profiles collected by the ASCENDS (Active Sensing of $\mathrm{CO}_{2}$ Emissions over Nights, Days, \& Seasons, https://www-air.larc.nasa.gov/cgibin/ArcView/ascends.2017?MERGE=1), ATom (Atmospheric Tomography, Wofsy et al., 2018), and

130 NOAA Carbon Cycle Aircraft Program (www.esrl.noaa.gov/gmd/ccgg/aircraft/) projects. The focus of this study will be on the $\mathrm{CO}_{2}, \mathrm{CH}_{4}$ and $\mathrm{CO}$ data acquired during Arctic-CAP.

\subsubsection{Aircraft and Payload}

Arctic-CAP flights were performed in a Mooney Ovation 3 (N617DH, Scientific Aviation). The

135 Mooney operated at a cruise speed of $170 \mathrm{kts}$ and reached profile altitudes of $5 \mathrm{~km}$ (17,000 feet) on each flight, with most legs lasting 4-5 hours and covering an average distance of $\sim 1350 \mathrm{~km}$. The average ascent and descent rates were limited to $\sim 100 \mathrm{~m} / \mathrm{min}$ to minimize hysteresis in the temperature and relative humidity measurements. The basic research payload flown on all six research missions included continuous in-situ $\mathrm{CO}_{2}, \mathrm{CH}_{4}, \mathrm{CO}, \mathrm{H}_{2} \mathrm{O}$, temperature and horizontal winds. The in-situ

140 measurements (Sweeney and McKain, 2019) followed the methodology described in Karion et al. [2013], and wind measurements followed the protocol outlined in Conley et al. [2013]. Programmable flask packages (PFPs; Sweeney et al., 2015) provided an independent check of the calibration scale of the continuous in situ $\mathrm{CO}_{2}, \mathrm{CH}_{4}$ and $\mathrm{CO}$ measurements, as well as samples for more than 50 different species including $\mathrm{N}_{2} \mathrm{O}, \mathrm{SF}_{6}$, and a variety of hydrocarbons, halocarbons and isotopes of carbon

145 (Sweeney et al., 2020). Carbonyl sulfide measured in the flask samples can be used as a tracer of gross primary productivity (GPP) (Montzka et al., 2007), while ethane, propane and C-13 isotope of $\mathrm{CH}_{4}$ provide another constraint on the source of the $\mathrm{CH}_{4}$ emissions. Each flight sampled a single 12-flask package providing a total of $\sim 84$ flasks per research mission to better understand the factors controlling local fluxes of $\mathrm{CO}_{2}, \mathrm{CH}_{4}$ and $\mathrm{CO}$ and the long-range transport of these species from low latitudes.

\section{2.1.3 GEOS Earth System Model \& Atmospheric $\mathrm{CO}_{2}, \mathrm{CO}$ and $\mathrm{CH}_{4}$ Modelling}

The GEOS (Molod et al., 2015; Rienecker et al., 2011) model is a complex yet flexible modeling system that describes the behavior of the land and atmosphere on a variety of spatial $(\sim 12.5-100 \mathrm{~km})$ and temporal (hourly to decadal) scales. GEOS includes both an atmospheric General Circulation Model (GCM) and data assimilation system that have been used to produce the widely-used Modern- 
155 Era Retrospective Analysis for Research and Applications (MERRA) (Rienecker et al., 2011) and MERRA-2 (Bosilovich et al., 2015; Gelaro et al., 2017). The GEOS Forward Processing (GEOS FP) system produces atmospheric analyses and 10-day forecasts in near real-time, which are used to provide forecasting support to NASA field campaigns and satellite instrument teams (e.g. Strode et al., 2018). GEOS has also been used extensively to study atmospheric carbon species (e.g. Allen et al., 2012; Ott et 160 al., 2015; Weir et al., 2020).

The GEOS setup utilized in this work simulates $\mathrm{CO}_{2}, \mathrm{CO}$ and $\mathrm{CH}_{4}$ simultaneously at nominal $0.5^{\circ}$ horizontal resolution, 72 vertical layers (up to $\sim 0.1 \mathrm{hPa}$ ) with trace gas output saved every 3 -hours. For $\mathrm{CO}_{2}$, the surface fluxes consist of 5 different components from a Low-order Flux Inversion (LoFI) package (Weir et al., 2020): 1) net ecosystem exchange (NEE) from the Carnegie Ames Stanford

165 Approach - Global Fire Emissions Database (CASA-GFED) mode with a parametric adjustment applied to match the atmospheric growth rate (Weir et al., 2020), 2) anthropogenic biofuel burning emissions, i.e., harvested wood product (Van Der Werf et al., 2003), 3) biomass burning emissions derived from the fire radiative power based Quick Fire Emissions Dataset (QFED; Darmenov and Da Silva, 2015) 4) fossil fuel emissions from the Open-source Data Inventory for Anthropogenic CO2 (ODIAC; Oda and Maksyutov, 2011), and 5) ocean exchange fluxes based on in situ measurements of the partial pressure of $\mathrm{CO}_{2}$ in sea-water from the Takahashi et al. (2009) dataset but adding back the inter-annual variability and applying a mean $\mathrm{pCO}_{2}{ }^{\mathrm{sw}}$ growth rate of $1.5 \mu \mathrm{atm} / \mathrm{yr}$ at each point every year. For $\mathrm{CO}$, the emissions include biomass burning emissions from QFED, and climatologies of fossil fuel and biofuel emissions and VOC fields (Duncan et al., 2007; Ott et al., 2010). Finally, the $\mathrm{CH}_{4}$ flux collection consists of five components: 1) wetland emissions from the process-based ecosystem model LPJ-wsl (Lund-PotsdamJena model, WSL version - Poulter et al., 2011), 2) biomass burning emissions from the QFED, 3) industrial and fossil fuel emissions from the Emissions Database for Global Atmospheric Research (EDGAR v4.3.2, Janssens-Maenhout et al., 2017; Crippa et al., 2018), 4) agricultural emissions from EDGAR v4.3.2 and 5) anthropogenic biofuel burning emissions from EDGAR v4.3.2. Note that since 180 the EDGAR v4.3.2 emissions record ends in 2012, the same set of values from 2012 were used for the year 2017. As shown later, this is not a bad assumption considering that for the majority of the ABoVE domain, the most critical $\mathrm{CH}_{4}$ emissions are from the wetlands sector. On the other hand, care was taken to use a version of the LPJ-wsl model that includes a state-of-the-art hydrology subroutine (TOPMODEL) to determine wetland area and its inter- and intra-annual dynamics (Zhang et al., 2016), 185 a permafrost and dynamic snow model (Wania et al., 2009) with explicit representation of the effects of snow and freeze/thaw cycles on soil temperature and moisture, and thus the $\mathrm{CH}_{4}$ emissions. Table 1 provides a summary of the flux components, their specifications and associated references. 
Table 1. Components of fluxes for simulation of atmospheric concentrations of $\mathrm{CO}_{2}, \mathrm{CO}$ and $\mathrm{CH}_{4}$ in GEOS. Flux components that are the primary drivers of observed signals within our study domain are highlighted in bold italics.

\begin{tabular}{|l|l|l|l|}
\hline \multicolumn{1}{|c|}{ Flux type } & \multicolumn{1}{c|}{$\begin{array}{c}\text { Used in } \\
\text { simulation of }\end{array}$} & $\begin{array}{c}\text { Inventory / Process- } \\
\text { based model name }\end{array}$ & \multicolumn{1}{c|}{ Reference } \\
\hline Fossil fuel & $\mathrm{CO}_{2}$ & ODIAC & Oda and Maksyutov, 2011 \\
Biofuel & $\mathrm{CO}_{2}$ & CASA-GFED3 & Van Der Werf et al., 2003 \\
NEE & $\mathrm{CO}_{2}$ & LoFI CASA & Weir et al., 2020 \\
Ocean & $\mathrm{CO}_{2}$ & LoFI Takahashi & Weir et al., 2020 \\
Biomass Burning / Fires & $\mathrm{CO}_{2}, \mathrm{CO}$, & QFED & Darmenov and Da Silva, 2015 \\
Fossil fuels \& biofuels & $\mathrm{CO}$ & Climatology & Duncan et al., 2007 \\
VOC & $\mathrm{CO}$ & GMI climatology & Duncan et al., 2007 \\
Wetlands & $\mathrm{CH} 4$ & LPJ-wsl & Poulter et al., 2011, Zhang et al., \\
Agriculture and waste & $\mathrm{CH}_{4}$ & EDGAR v4.3.2 & Crippa et al., 2018 \\
Biofuels & $\mathrm{CH}_{4}$ & EDGAR v4.3.2 & Crippa et al., 2018 \\
Industrial and fossil fuel & $\mathrm{CH}_{4}$ & EDGAR v4.3.2 & Crippa et al., 2018 \\
\hline
\end{tabular}

We have assessed global and pan-Arctic budgets (Tables 2 and 3) and compared against existing studies and estimates to establish the fidelity of the model fluxes for large-scale assessments.

Table 2. GEOS $\mathrm{CO}_{2}$ Flux Estimates (PgC yr-1) for 2017. Flux emissions are specified for (a) the natural land sink component, which includes the sum of NEE and biomass burning, and (b) all anthropogenic source components, which include fossil fuel and biofuel burning.

\begin{tabular}{|c|c|cc|cc|}
\hline \multicolumn{2}{|c|}{ ABoVE Domain } & \multicolumn{2}{c|}{ pan-Arctic (>48 N) } & \multicolumn{2}{c|}{ Global } \\
\hline Land Sink & Fuel Sources & Land Sink & Fuel Sources & Land Sink & Fuel Sources \\
\hline-0.32 & 0.11 & -1.84 & 1.37 & -3.28 & 11.08 \\
\hline
\end{tabular}

$\mathrm{CO}_{2}$ flux estimates indicate that the ABOVE domain is a $0.32 \mathrm{PgC}$ sink for our study year, 2017. This represents about $17 \%$ of the calculated pan-Arctic terrestrial carbon sink, which is consistent with the fraction of the land area $>48 \mathrm{~N}$ represented by the ABoVE domain ( 16\%). Perhaps more significantly,

200 the $1.84 \mathrm{PgC}$ pan-Arctic sink represents $56 \%$ of the global sink for 2017 . We attribute this large uptake to the vast boreal forests $>48 \mathrm{~N}$, particularly in Siberia (Sasakawa et al., 2013), where the contemporary Arctic tundra is thought to be nearly carbon neutral with uncertainties allowing for a small to moderate sink or a small source (McGuire et al., 2016). These findings are also consistent with Wunch et al. (2013) who used GOSAT satellite data and TCCON ground-based column measurements to determine

205 that interannual variability in Northern Hemisphere $\mathrm{CO}_{2}$ uptake was dominated by changes in the boreal forest. More recent studies, such as Welp et al. (2016) and Commane et al. (2017) have also used atmospheric inversions to highlight that $>90 \%$ of the carbon sink in the northern high latitudes reside in the boreal forests. Our simple forward model simulations and the Arctic-CAP data provide a unique opportunity to assess the validity of these previous findings over the ABoVE domain. Sub-regional flux 210 estimates within the ABoVE domain are part of ongoing investigations and will be captured in future studies. 
Table 3. GEOS $\mathrm{CH}_{4}$ Flux Estimates ( $\mathrm{TgCH}_{4}$ yr-1) for 2017. $\mathrm{CH}_{4}$ flux emissions are specified for (a) the wetland component, and (b) all source components, which include wetlands, industrial and fossil fuel, agriculture and waste, biomass burning, biofuel burning and other natural emissions.

\begin{tabular}{|c|c|c|c|c|c|}
\hline \multicolumn{2}{|c|}{ ABoVE Domain } & \multicolumn{2}{c|}{ pan-Arctic (>48 N) } & \multicolumn{2}{c|}{ Global } \\
\hline Wetland & All Sources & Wetland & All Sources & Wetland & All Sources \\
\hline 9.01 & 11.64 & 21.74 & 52.03 & 187.39 & 536.01 \\
\hline
\end{tabular}

215 Examination of the specified $\mathrm{CH}_{4}$ flux estimates for the ABoVE domain (Table 4) reveal a remarkable result: $78 \%$ of the emissions, $9.01 \mathrm{TgCH}_{4} \mathrm{yr}^{-1}$, come from wetlands. Furthermore, ABoVE wetlands emissions account for $41 \%$ of pan-Arctic $\mathrm{CH}_{4}$ wetland emissions. Both results suggest a disproportionately large contribution of North American wetlands to the regional $\mathrm{CH}_{4}$ budget. Placing this in a larger context, the $52 \mathrm{TgCH}_{4} \mathrm{yr}^{-1}$ from all pan-Arctic emissions account for only about $10 \%$ of

220 the global emissions. Our pan-Arctic $\mathrm{CH}_{4}$ emissions estimate of $52 \mathrm{TgCH}_{4} \mathrm{yr}^{-1}$ is only $60 \%$ of the $82-84$ $\mathrm{TgCH}_{4} \mathrm{yr}^{-1}$ determined by Thompson et al. (2017) for latitudes $>50 \mathrm{~N}$ and the period 2005-2013. The reasons for this large discrepancy are unclear, particularly since the Thompson et al. (2017) study derived their estimate from an inversion of atmospheric $\mathrm{CH}_{4}$ observations; previously, such top-down estimates have tended to be lower than most forward model emissions estimates. Subtracting the 11

$225 \mathrm{TgCH}_{4} \mathrm{yr}^{-1}$ we estimate for the $\mathrm{ABoVE}$ domain from our pan-Arctic value leaves $41 \mathrm{TgCH}_{4} \mathrm{yr}^{-1}$ for the remainder of the pan-Arctic. Future work with additional observations and model simulations will help us understand how specific sectors in the ABoVE domain can better capture the complexity of panArctic $\mathrm{CH}_{4}$ emissions. Our overall model value of $536 \mathrm{TgCH}_{4} \mathrm{yr}^{-1}$ for global $\mathrm{CH}_{4}$ emissions in 2017 falls just outside the range of annual emissions estimates for the decade 2008-2017 (Saunois et al., 230 2019). This discrepancy is primarily due to the fact that we are looking at different time periods and unlike Saunois et al. (2019), we do not extrapolate the EDGARv4.3.2 dataset using the extended FAO$\mathrm{CH}_{4}$ emissions and/or British Petroleum statistical review of fossil fuel production and consumption (see Equation 1 in Saunois et al., 2019); instead, we adopt a much more simplistic approach of repeating the EDGARv4.3.2 from 2012 for the year 2017. Contrary to the emissions from the coal, oil and gas 235 sector, our wetland methane flux emissions are obtained from the LPJ-wsl model (Table 1). LPJ-wsl is one of the prognostic models that provide wetland emission estimates to the global methane budget (Table 2 in Saunois et al., 2019). It is not surprising then that our global wetland $\mathrm{CH}_{4}$ emission estimates for 2017 is in line with both the bottom-up (100-183 $\left.\mathrm{TgCH}_{4} \mathrm{yr}^{-1}\right)$ and top-down (155-217 Tg $\mathrm{CH}_{4} \mathrm{yr}^{-1}$ ) estimates used in the global methane budget estimate. 


\section{Results}

\subsubsection{Analysis of Profiles}

Table 4. Arctic-CAP 2017 campaign summary

\begin{tabular}{|l|c|c|}
\hline Campaign & $\begin{array}{c}\text { Start } \\
\text { (DOY) }\end{array}$ & $\begin{array}{c}\text { End } \\
\text { (DOY) }\end{array}$ \\
\hline Apr/May & 116 & 124 \\
June & 157 & 170 \\
July & 190 & 202 \\
August & 229 & 242 \\
September & 251 & 271 \\
Oct/Nov & 291 & 310 \\
\hline
\end{tabular}

245 Vertical profiles of $\mathrm{CO}_{2}, \mathrm{CH}_{4}$ and $\mathrm{CO}$ were acquired during 56 flights over the six Arctic-CAP campaigns from late April (day of year (DOY) 116) through early November (DOY 310) 2017 (Table 4). Figure 4 presents the composite vertical profile data for each campaign. The monthly composite $\mathrm{CO}_{2}, \mathrm{CH}_{4}$ and $\mathrm{CO}$ vertical profiles capture the expected variations in the seasonal cycle. The composite profiles also show more variability in the boundary layer (altitudes $<3000$ masl) within each month and across months than in the free troposphere for $\mathrm{CO}_{2}$ and $\mathrm{CH}_{4}$ (altitudes $>3000$ masl). Unlike $\mathrm{CO}_{2}$ and $\mathrm{CH}_{4}, \mathrm{CO}$ variability in the free troposphere is significantly greater in July and October than the boundary layer showing either long-range transport of $\mathrm{CO}$ or $\mathrm{CO}$ injected high (>3000 masl) into the troposphere by local wildfires.

A clearer picture of the vertical gradients between the free troposphere and the boundary layer can be seen by subtracting free tropospheric means from measurements below 3000 masl. The $\mathrm{CO}_{2}$ gradients between the measurements below 3000 masl and average daily free troposphere values show a drawdown in the boundary layer for most of the profiles starting in June and lasting until the end of the September campaign (Fig. 5). The drawdown signal in $\mathrm{CO}_{2}$ over the Northern Alaska Tundra (often referred to as the "North Slope") was most pronounced in mid-July and continued through the

260 September campaign. The $\mathrm{CO}_{2}$ drawdown in the more southerly regions of the Boreal Cordillera and Alaskan Boreal Interior peaked in August. By the October campaign many regions were showing significant enhancements in the boundary layer $\mathrm{CO}_{2}$ mole fraction relative to the free troposphere. On the other hand, for both $\mathrm{CH}_{4}$ and $\mathrm{CO}$, significant enhancements were observed from June through early November. Methane enhancements over the Northern Alaska Tundra $\mathrm{CH}_{4}$ enhancements were observed

265 from July onward, consistent with patterns observed at the long-term surface monitoring station in Utqiagvik (Sweeney et al., 2016). Similarly, boundary layer $\mathrm{CO}_{2}$ and $\mathrm{CH}_{4}$ are both most enhanced in September and October on the North Alaska Tundra. Due to the high variability in CO above 3000 masl during July and October (Fig. 4), it is more difficult to use this approach to derive $\mathrm{CO}$ enhancements from surface fluxes. To avoid the impact of fire-based CO that has been injected into the free troposphere, the mean background value is taken from measurements above 4000 masl. This analysis 
shows that Canadian Taiga and Alaskan Boreal Interior are the predominant sources of boundary layer $\mathrm{CO}$ emissions likely reflecting fires in these regions at that time. It should be noted that large enhancement values for $\mathrm{CO}_{2}, \mathrm{CH}_{4}$ and $\mathrm{CO}$ were observed with the Alaskan Boreal Interior, which were the result of samples taken in the early morning (10:00 local time) before the boundary layer has fully developed (typically around 11:00-12:00 local time). This trapping of night-time emissions results in significant enhancements that quickly taper off with altitude. These measurements were typically taken during the first profile out of Fairbanks where the majority of the Arctic-CAP flights originated.

\subsubsection{Model Data Comparisons}

Aircraft profiles that measure the gradient from the boundary layer into the free troposphere are particularly useful for evaluating atmospheric models and for separating errors and uncertainties related to atmospheric transport and surface flux model simulations. This is demonstrated by comparing surface flux models for $\mathrm{CO}_{2}, \mathrm{CH}_{4}$, and $\mathrm{CO}$ using a single GCM to evaluate both the transport features and the flux model specifications. For the data-model comparison, the aircraft observations are aggregated to 10s averages and the model 4D fields (latitude, longitude, altitude and time) are sampled at the location and time of those $10 \mathrm{~s}$ averages. Sampling with the 10 s averages reduces the spatial representativeness error between the model grid cell and the aircraft observations.

\subsubsection{Point by Point Comparison}

In the GEOS model run used for these comparisons, an effort was made to match the global atmospheric burdens of $\mathrm{CO}_{2}, \mathrm{CH}_{4}$ and $\mathrm{CO}$; however, given the uncertainties in the sources and sinks of these trace gases and in the representation of long-range and local atmospheric transport, it is not uncommon to have mean offsets between the observed and the modeled mole fractions. To evaluate surface fluxes in the ABoVE domain, it is important to consider both the impact of regional-scale fluxes and long-range transport processes that control the mole fractions of $\mathrm{CO}_{2}, \mathrm{CH}_{4}$ and $\mathrm{CO}$ throughout the ABoVE domain. A time series comparison of the modeled and the observed $\mathrm{CO}_{2}, \mathrm{CH}_{4}$ and $\mathrm{CO}$ mole

295 fractions (Fig. 6) suggests that gross features of the seasonal cycles are matched, although some significant differences require detailed analysis by considering different elements of each vertical profile.

\subsubsection{Free Troposphere Comparisons}

As demonstrated from the analysis of the boundary layer enhancements, it is useful to subtract the 300 average free tropospheric mole fraction from each profile to better understand the local influences within a particular profile. Differences in the mean free tropospheric values, however, can be a valuable indicator of how large-scale biases in the model influence point-to-point comparisons.

In the case of $\mathrm{CO}_{2}$, the mean daily $\mathrm{CO}_{2}$ mole fraction in the observed free troposphere is increasing faster than modeled values over the course of 6 research missions. The largest offset exceeds a mean 305 value of $\sim 2$ ppm (observed - modeled) during the September campaign (Fig. 7). Based on the available model runs, it is difficult to diagnose what causes this offset, although a few hypotheses can be put forward. Given the decreasing latitudinal gradient for $\mathrm{CO}_{2}$ in the free troposphere at this time of year, 
the offset could be explained by sluggish meridional transport in the model. Alternatively, exaggerated biological uptake in the model in regions outside the study area could be pulling down the $\mathrm{CO}_{2}$ in modeled free troposphere more rapidly than the drawdown observed over the ABoVE domain. Measured $\mathrm{CH}_{4}$ increases faster than modeled $\mathrm{CH}_{4}$ over the course of the campaign. Given the decreasing meridional gradient for $\mathrm{CH}_{4}$ that exists during the summer months, sluggish transport could explain the difference between model and observations. Alternatively, modeled June-July-August emissions of $\mathrm{CH}_{4}$ in areas surrounding the $\mathrm{ABoVE}$ domain could be underestimated, leading to slower increase in modeled free tropospheric $\mathrm{CH}_{4}$.

Finally, the difference between modeled and observed mole fractions of $\mathrm{CO}$ in the free troposphere is mainly driven by inaccuracies in the modeled $\mathrm{CO}$ from fire plumes both within and outside the ABoVE domain. Figures 4, 6 and 7 show observations of large $\mathrm{CO}$ enhancements above 4000 masl during the July, August and October/November campaigns. Given the large excursions in the free tropospheric CO between different profiles, local fires were likely responsible for these enhancements. Accurately simulating the injection height of fire plumes is challenging (Freitas et al., 2007; Strode et al., 2018). The GEOS model distributes biomass burning emissions throughout the planetary boundary layer (PBL) to represent injection above the surface layer, but this method can result in underestimated local emissions for fire plumes detraining in the free troposphere. In regions remote to the ABoVE domain, emissions can be mixed and lofted by large-scale weather systems, which may explain why the model performs better in simulating long-range $\mathrm{CO}$ plume transport than it does in capturing the $\mathrm{CO}$ enhancements from local fires. The observation-model mismatch is likely compounded by the inability of the model to accurately simulate the subgrid-scale vertical mixing necessary for capturing vertical profiles for local sources.

\subsubsection{Boundary Layer Comparisons}

Accurately modeling boundary layer mole fractions of $\mathrm{CO}_{2}, \mathrm{CH}_{4}$ and $\mathrm{CO}$ depends on an accurate representation of two key factors. First, there is a need to accurately model the local surface-atmosphere flux and second there is a need to correctly model the physical evolution of the PBL, as well as horizontal transport and vertical mixing out of the PBL into the free troposphere. GCMs have limited

335 horizontal and vertical resolution and require parameterizations to predict both the rate of change and the absolute value of the PBL height over the course of the day. Errors in PBL mixing directly impact the tracer mole fraction estimate. Overestimation of the PBL height causes an artificial dilution of the impact of surface flux. Conversely, underestimation of the PBL height results in amplification of the impact of a surface flux on the simulated PBL mole fraction. Additionally, GCMs typically simulate large-scale horizontal gradients more accurately than PBL height unless there are large topographic changes that occur on horizontal scales less than the model resolution (for GEOS, 0.5 degree). This is because such large-scale patterns are generally well-constrained by the millions of in situ and satellite observations incorporated into meteorological analyses while PBL mixing is represented by highly simplified parameterizations

345 The three carbon species that we investigate in this study provide different diagnostic information about the model transport and flux specifications. In the case of a gas like CO that often comes from a specific point source in the Arctic, accurate placement of the emissions, both in the horizontal and the vertical, 
and the modeled wind direction are critical factors. The ABoVE domain is made up of large expanses of forest and tundra in which $\mathrm{CO}_{2}$ fluxes are more uniformly distributed, making the transport accuracy of individual plumes a less critical factor for simulating $\mathrm{CO}_{2}$. Accurately estimating $\mathrm{CH}_{4}$ mole fractions may be more sensitive to horizontal transport in the $\mathrm{PBL}$ if $\mathrm{CH}_{4}$ emissions are dominated by specific features such as lakes or wetlands, or anthropogenic point sources from oil and gas production such as those observed on the North Slope (Floerchinger et al., 2019). However, we observed consistent PBL $\mathrm{CH}_{4}$ enhancements throughout each campaign (Fig. 5), suggesting a spatial homogeneity in $\mathrm{CH}_{4}$ emissions rather than emissions from specific point sources.

\subsubsection{The advantage of vertical trace gas gradients}

While individual mole fraction measurements are challenging to reproduce given errors in both modeled surface fluxes and transport, the vertical profile provides a unique opportunity for removing significant uncertainties in transport in order to better assess the surface flux model of a specific long-lived tracer. Assuming that horizontal transport is a relatively small source of bias and the upper part of the free troposphere (>3000 masl) is largely unaffected by local processes, it is possible to use the information in the vertical profile to reduce the effects of vertical transport. This can be estimated by vertically integrating the net change in the PBL due to a surface flux from the surface to a specific altitude that is well above the boundary layer. For this study, almost all the enhancements for $\mathrm{CO}_{2}$ and $\mathrm{CH}_{4}$ were observed below 3000 masl. By subtracting the average free tropospheric (FT) values in both the model and the measurements and averaging the resulting enhancements or depletions for each profile mapped on equal altitude bins from surface to 3000 masl, we quantify a total enhancement resulting from the surface flux (Fig. 8). The resulting measured and modeled boundary layer enhancements show good matches for all three gases.

370 The average measured enhancement in $\mathrm{CO}_{2}$ and $\mathrm{CH}_{4}$ below 3000 masl is correlated with the forward model such that more than $50 \%$ and $36 \%$, respectively, of the variability observed is captured by the model (Fig. 8). The average CO enhancements in the lower 3000 masl is captured by the model with lesser accuracy - in fact, the model only captures $26 \%$ of the observed variability along with a significant bias throughout the growing season.

\subsubsection{Average $\mathrm{CO}_{2}$ enhancement}

To understand the true value of the aircraft profile in evaluating the ability of the surface flux model to reproduce observed fluxes over large regional expanses, it is useful to rigorously compare the differences between modeled and observed near-surface enhancements. The enhancements of $\mathrm{CO}_{2}$ below 3000 masl shown in Fig. 8 for both data and the GEOS model are well correlated. As expected, during April/May we see very little change in the average enhancements below 3000 masl, while June and July and August show significant drawdown, followed by enhancements in September and October/November (Fig. 6 and 8). The modeled enhancements in the lower 3000 masl reproduce the observations suggesting that the surface flux of $\mathrm{CO}_{2}$ throughout most of the ABoVE domain is accurately modeled by GEOS.

385 Despite the overall agreement indicated by aggregated statistics, a closer look shows significant differences in observed and modeled $\mathrm{CO}_{2}$ enhancements for many individual flight days (Fig. 9). 
Inspection of individual profiles (Fig. 10) reveal that in some cases the model is not capturing nearground stratification. This is not surprising given that the observations have a much higher vertical resolution than the model's vertical resolution, which is $\sim 100 \mathrm{~m}$ in the PBL. Consequently, the observed mole fraction values are much higher than the model estimates because the model is not able to capture the stratification in the river valleys in the interior parts of the ABoVE domain. However, the overall modeled vertical gradients in $\mathrm{CO}_{2}$ match the observations suggesting that the large-scale vertical transport of emissions is accurately simulated above $\sim 1000$ masl. As an example, the set of profiles from July 10 (Fig. 10) demonstrates that, although infrequent, high PBL heights and emissions from fires (as indicated by large ( $>400 \mathrm{ppb}$ ) enhancements in $\mathrm{CO}$ ) add some uncertainty to the average BL enhancement values. Both of these factors impact the mean free tropospheric correction and altitude of integration that we have chosen to accurately capture the total $\mathrm{CO}_{2}$ enhancement from the surface fluxes.

\subsubsection{Average $\mathrm{CH}_{4}$ enhancement}

400 Although the correlation between the observed and modeled average enhancements of $\mathrm{CH}_{4}$ is significant, there are some key deviations that should be noted. In particular, we see some clear biases in the seasonality where the enhancements in the early part of the season are underestimated by the model while the enhancements in the later part of the season are overestimated. This is demonstrated both by the comparisons of average enhancements (Fig. 8) and of mole fraction enhancements below 4053000 masl (Fig. 9) where the mean difference (observed - modeled) switches from positive to negative over the course of the study period. The Arctic-CAP profile observations provide a critical point of comparison to which future surface flux models of $\mathrm{CH}_{4}$ can be compared, helping to identify areas where process improvements are needed.

\subsubsection{Average CO enhancement}

410 The comparison of observed and modeled average enhancements of $\mathrm{CO}$ is less useful because some of the critical assumptions we make for this comparison are designed to shed light on surface processes affecting $\mathrm{CO}_{2}$ and $\mathrm{CH}_{4}$. The biggest limitation in the $\mathrm{CO}$ simulation for interpreting vertical profile observations appears to be in the accuracy of the vertical distribution of $\mathrm{CO}$ emissions. While the model shows an increase in mole fractions during the July and October/November campaigns, the extreme

415 mole fractions in the observations are twice that of the model (Fig. 6). A good example of how the model and the observed mole fractions are different can be seen on July 10, 2017 (Fig. 10) during a flight up the Mackenzie River in the Northwest Territories of Canada. Here, large enhancements of CO $\left(>400 \mathrm{ppb}\right.$ ) are observed at altitudes between 3000 and 5000 masl while $\mathrm{CH}_{4}$ and $\mathrm{CO}_{2}$ boundary layer enhancements are observed below 3000 masl in most of the profiles measured that day. The $\sim 100 \mathrm{ppb}$

$420 \mathrm{CO} / \mathrm{ppm} \mathrm{CO}_{2}$ ratio and the large $\mathrm{CO}$ enhancement not only support the idea that a fire is the source but that the fire is nearby $(<100 \mathrm{~km})$. Both the magnitude and altitude of the $\mathrm{CO}$ enhancement point to a few critical limitations in the model that was less important for $\mathrm{CO}_{2}$ and $\mathrm{CH}_{4}$. First, most GCMs, including GEOS, do not take into account the massive heat source that fires provide to correctly model the injection of fire emissions above the boundary layer. Second, the fire radiative power observations used to estimate emissions can be obscured by thick clouds or aerosols resulting in the emissions 
estimates missing some fire hotspots. Third, the heterogenous nature of fires as a surface source of CO means that any inaccuracies in horizontal transport or location of the fire will play a large role in the ability of the model to accurately reproduce the observations. Fourth, the lack of diurnal cycle in biomass burning emissions from the emission database (QFED; Table 1) may result in 'temporal aggregation errors', whereby the model simulations may miss the high emission values that coincide with the daytime aircraft observations.

\subsubsection{Model-data mismatch over ecoregions}

It is also helpful to break the model-data mismatch into regional domains (Fig. 11) to obtain more insight into where the observed and modeled concentrations diverge, and whether the difference can be attributed to the underlying fluxes or deficiencies in the model's atmospheric transport. For most regions and times of year, the difference in average $\mathrm{CO}_{2}$ enhancements is not statistically significant; however, there are certain regions such as the Northern Tundra of Alaska, where the modeled average $\mathrm{CO}_{2}$ enhancements are significantly different and amplify a pattern that is observed over other regions. In early spring, the model slightly overestimates observed boundary layer enhancements but a month

440 later the model underestimates drawdown. Figures 6 and 11 suggest that the model drawdown in $\mathrm{CO}_{2}$ is preceding the observed early-summer $\mathrm{CO}_{2}$ drawdown. The difference between observed and modeled enhancements change sign again during the July flight in Northern Tundra Alaska with an underestimation of the drawdown. Similar patterns can be observed in the Canadian Boreal Cordillera, suggesting that the timing of the summertime drawdown is too early in the model in this region. Over

445 the same period, however, comparisons over the Western Alaska Tundra depict opposite patterns (although far more subtle). While the offsets in the fall months are smaller, there is the suggestion that the enhancements in the Southern Arctic and Canadian Taiga ecoregions are both underestimated in the model. For $\mathrm{CH}_{4}$, the seasonal bias (underestimation in the spring and overestimation between JulySeptember) in the integrated enhancements between observations and models stands out as the most

450 significant feature. The notable exceptions are again the Northern Tundra of Alaska and Canadian Boreal Cordillera, where $\mathrm{CH}_{4}$ enhancements in July and at the end of October are significantly underestimated. For reasons explained earlier, the CO comparison is less informative. However, if one were to analyze data from the month of September, which had no significant influence from fires in the free troposphere, it would suggest that the model continues to underestimate the impact of CO 455 emissions across all regions.

\subsubsection{Separating local, region and global vertical gradients}

By extracting enhancements below 3000 masl from the observations and the model we have largely separated two major sources of biases and uncertainty in a model-data comparison - vertical transport and offsets in background mole fraction. However, it should be acknowledged that gradients between

460 the boundary layer and free troposphere are not controlled exclusively by local fluxes and that in the Arctic, in particular, vertical gradients can be controlled by non-local influences. To explore the impact of long-range transport Parazoo et al. (2016) preformed three simulations to better understand the drivers of the vertical gradient over Alaska and found that $48 \%$ of the amplitude (April/MayJuly/August) in the seasonal vertical gradient was driven by local fluxes from Alaska while the rest was 
465 driven by fluxes from the rest of the Arctic $(11 \%)$ and low latitude $(<60 \mathrm{~N}, 41 \%)$. For $\mathrm{CO}_{2}$, the impact of long-range transport to the vertical gradient is complicated by the difference in timing of the initial drawdown in the spring and the uptick in the fall at low latitudes verses that of high latitudes. The earlier drawdown of $\mathrm{CO}_{2}$ at low latitudes and the transport of that air via the free troposphere to Arctic significantly reduces the negative vertical gradient in the Arctic. At the same time, the early uptick of

$470 \mathrm{CO}_{2}$ mole fraction in the Arctic relative to the low latitudes enhances the positive vertical gradient in the early fall (Parazoo et al., 2016).

To account for the background vertical gradient in $\mathrm{CH}_{4}$ entering the contiguous US, Baier et al. (2020) and Lan et al. (2019) subtracted 12-15 ppt from the vertical gradient to account for a preexisting gradient in $\mathrm{CH}_{4}$ coming onto the continent. Analysis of the background gradient suggests that this

475 preexisting vertical gradient is a combination of upstream emissions and wind shear which separates the origin of the boundary layer air from that of the free troposphere. Large meridional gradients in $\mathrm{CH}_{4}$, such as those observed in the mid latitudes, will drive depletion of the free troposphere relative to that of the boundary layer over the Arctic. Similarly, CO vertical gradients will also be affected by non-local fluxes and wind shear between the boundary layer and the free troposphere. In the case of $\mathrm{CO}$ and $\mathrm{CH}_{4}$ there is also likely to be a vertical gradient that is influenced by the oxidation of these molecules. However, given the relatively long residence time of these molecules and the low sampling altitude in the free troposphere (between 3000 and 5000 masl) of this experiment, this effect is small. From this perspective, the preexisting vertical gradient outside the domain of interest illustrates the importance of the model accuracy in non-local fluxes and the importance of long-range transport in the analysis. One approach ensuring a better boundary conditions is to use a global inversion (e.g. CarbonTracker (Peters et al., 2007)) to initialize the local region where the prognostic flux model is then run to simulate local fields as is done to initialize regional Legrangian inversion models (e.g. Hu et al., 2019).

\section{Conclusions}

The Arctic-CAP campaign was composed of 6 different research missions from April to November 2017. It sampled $\mathrm{CO}_{2}, \mathrm{CH}_{4}$ and $\mathrm{CO}$ vertical profiles from the surface to 5000 masl across the ABoVE domain in Alaska and Northwestern Canada, covering 6 major Arctic ecoregions. Arctic-CAP airborne surveys included large Tundra and Boreal ecosystems that are the likely sources of large changes in the

495 seasonal cycle of $\mathrm{CO}_{2}$ and have been the subject of great speculation about future emissions of $\mathrm{CH}_{4}$. Arctic-CAP's $\mathrm{CO}_{2}, \mathrm{CH}_{4}$ and $\mathrm{CO}$ profiles provide an excellent basis for evaluating the surface flux models used within state-of-the-art atmospheric transport models, and thus, are an important tool for understanding carbon cycle feedbacks. Comparisons of Arctic-CAP $\mathrm{CO}_{2}, \mathrm{CH}_{4}$ and $\mathrm{CO}$ observations against GEOS model results show that: (a) for $\mathrm{CO}_{2}$, the flux model (land and ocean biosphere and fossil

500 fuel) reproduces seasonal and regional depletions and enhancements observed by aircraft profiles after adjusting for small systematic offsets; (b) for $\mathrm{CH}_{4}$, the model simulations agree reasonably well with the observed vertical profiles, but the model underestimates $\mathrm{CH}_{4}$ in the spring and overestimates it in the fall. Modeled North Slope $\mathrm{CH}_{4}$ is underestimated throughout the measurement period pointing to 
deficiencies in the wetland flux specifications over this ecoregion; and (c) for $\mathrm{CO}$, the comparison

505 between modeled and observed values were confounded by large biomass burning enhancements in the free troposphere that were not captured in the model. Despite these minor shortcomings, the forward model estimates for $\mathrm{CO}_{2}$ and $\mathrm{CH}_{4}$ represent a marked improvement in model-data differences compared to those done previously for CARVE (Chang et al., 2014; Commane et al., 2017). Results and the flux budgets demonstrate that model representation of $\mathrm{CO}_{2}$ and $\mathrm{CH}_{4}$ for northern high-latitude ecosystems

510 have advanced significantly since the state-of-the-science survey by Fisher et al. (2014). Inversions of the Arctic-CAP data using these fluxes as the prior estimate should further refine the flux estimates and the budget for the ABoVE domain. We note that our comparisons used only GEOS forward model values and slightly different model-data mismatches may be obtained by using a different transport model.

515 Finally, this study highlights the value of collocated airborne $\mathrm{CO}_{2}, \mathrm{CH}_{4}$ and $\mathrm{CO}$ vertical profiles for quantifying model strengths and weaknesses. This feedback is essential to improve model characterization of both surface-atmosphere fluxes and atmospheric transport and to improve our confidence in the accuracy of projections of future conditions. We strongly recommend regular, systematic $\mathrm{CO}_{2}, \mathrm{CH}_{4}$ and $\mathrm{CO}$ vertical profile observations across the Arctic as an important and cost520 effective method to monitor the Arctic system and abrupt transformations or potential tipping points in the permafrost carbon feedback.

\section{Data Availability}

Aircraft data can be found at https://doi.org/10.3334/ORNLDAAC/1658 


\section{Author contributions}

CS, KM, CM, AC did experimental design. CS, TN, SW, KM carried out experiment. CS, AC, CM, RB, SW, LS, LH helped with manuscript.

\section{Competing interests}

The authors declare that they have no conflict of interest.

\section{Acknowledgements}

This research was supported by the NASA Terrestrial Ecology Program award \#NNX17AC61A, "Airborne Seasonal Survey of $\mathrm{CO}_{2}$ and $\mathrm{CH}_{4}$ Across ABOVE Domain", as part of the Arctic-Boreal Vulnerability Experiment (ABoVE). A portion of the research presented in this paper was performed at Aeronautics and Space Administration. GEOS model runs and the work of AC was supported by funding from the NASA ROSES-2016 Grant/Cooperative Agreement NNX17AD69A.

\section{References}

Allen, M., Erickson, D., Kendall, W., Fu, J., Ott, L., and Pawson, S.: The influence of internal model variability in GEOS-5 on interhemispheric CO2 exchange, Journal of Geophysical Research-Atmospheres, 117, 10.1029/2011jd017059, 2012.

Baier, B. C., Sweeney, C., Choi, Y., Davis, K. J., DiGangi, J. P., Feng, S., Fried, A., Halliday, H., Higgs, J., Lauvaux, T., Miller, B. R., Montzka, S. A., Newberger, T., Nowak, J. B., Patra, P., Richter, D., Walega, J., and Weibring, P.: Multispecies Assessment of Factors Influencing Regional CO2 and CH4 Enhancements During the Winter 2017 ACT-America Campaign, Journal of Geophysical Research-Atmospheres, 125, 10.1029/2019jd031339, 2020.

Baldocchi, D. D., Krebs, T., and Leclerc, M. Y.: "Wet/dry Daisyworld": a conceptual tool for quantifying the spatial scaling of heterogeneous landscapes and its impact on the subgrid variability of energy fluxes, Tellus Ser. B-Chem. Phys. Meteorol., 57, 175-188, 10.1111/j.1600-0889.2005.00149.x, 2005.

Bosilovich, M. G., Chern, J.-D., Mocko, D., Robertson, F. R., and da Silva, A. M.: Evaluating Observation Influence on Regional Water Budgets in Reanalyses, J. Clim., 28, 3631-3649, 10.1175/jcli-d-14-00623.1, 2015. 
Chang, R. Y. W., Miller, C. E., Dinardo, S. J., Karion, A., Sweeney, C., Daube, B. C., Henderson, J. M., Mountain, M. E., Eluszkiewicz, J., Miller, J. B., Bruhwiler, L. M. P., and Wofsy, S. C.: Methane emissions from Alaska in 2012 from CARVE airborne observations, Proc. Natl. Acad. Sci. U. S. A., 111, 16694-16699, 10.1073/pnas.1412953111, 2014. Commane, R., Lindaas, J., Benmergui, J., Luus, K. A., Chang, R. Y. W., Daube, B. C., Euskirchen, E. S., Henderson, J. M., Karion, A., Miller, J. B., Miller, S. M., Parazoo, N. C., Randerson, J. T., Sweeney, C., Tans, P., Thoning, K., Veraverbeke, S., Miller, C. E., and Wofsy, S. C.: Carbon dioxide sources from Alaska driven by increasing early winter respiration from Arctic tundra, Proc. Natl. Acad. Sci. U. S. A., 114, 5361-5366, 10.1073/pnas.1618567114, 2017.

Crippa, M., Guizzardi, D., Muntean, M., Schaaf, E., Dentener, F., van Aardenne, J. A., Monni, S., Doering, U., Olivier, J. G. J., Pagliari, V., and Janssens-Maenhout, G.: Gridded emissions of air pollutants for the period 1970-2012 within EDGAR v4.3.2, Earth Syst. Sci. Data, 10, 1987-2013, 10.5194/essd-10-1987-2018, 2018.

Darmenov, A. S., and Da Silva, A. M.: The Quick Fire Emissions Dataset (QFED): Documentation of versions 2.1, 2.2 and 2.4., NASA Technical Report Series on Global Modeling and Data Assimilation, 38, 2015.

Duncan, B. N., Strahan, S. E., Yoshida, Y., Steenrod, S. D., and Livesey, N.: Model study of the cross-tropopause transport of biomass burning pollution, Atmos. Chem. Phys., 7, 3713-3736, 10.5194/acp-7-3713-2007, 2007.

Fisher, J. B., Sikka, M., Oechel, W. C., Huntzinger, D. N., Melton, J. R., Koven, C. D., Ahlstrom, A., Arain, M. A., Baker, I., Chen, J. M., Ciais, P., Davidson, C., Dietze, M., El-Masri, B., Hayes, D., Huntingford, C., Jain, A. K., Levy, P. E., Lomas, M. R., Poulter, B., Price, D., Sahoo, A. K., Schaefer, K., Tian, H., Tomelleri, E., Verbeeck, H., Viovy, N., Wania, R., Zeng, N., and Miller, C. E.: Carbon cycle uncertainty in the Alaskan Arctic, Biogeosciences, 11, 4271-4288, 10.5194/bg-11-4271-2014, 2014.

Floerchinger, C., McKain, K., Bonin, T., Peischl, J., Biraud, S. C., Miller, C., Ryerson, T. B., Wofsy, S. C., and Sweeney, C.: Methane emissions from oil and gas production on the North Slope of Alaska, Atmospheric Environment, 218, 10.1016/j.atmosenv.2019.116985, 2019.

Freitas, S. R., Longo, K. M., Chatfield, R., Latham, D., Silva Dias, M. A. F., Andreae, M. O., Prins, E., Santos, J. C., Gielow, R., and Carvalho, J. A., Jr.: Including the sub-grid scale plume rise of vegetation fires in low resolution atmospheric transport models, Atmospheric Chemistry and Physics, 7, 3385-3398, 10.5194/acp-7-3385-2007, 2007.

Gelaro, R., McCarty, W., Suárez, M. J., Todling, R., Molod, A., Takacs, L., Randles, C. A., Darmenov, A., Bosilovich, M. G., Reichle, R., Wargan, K., Coy, L., Cullather, R., Draper, C., Akella, S., Buchard, V., Conaty, A., da Silva, A. M., Gu, W., Kim, G.-K., Koster, R., Lucchesi, R., Merkova, D., Nielsen, J. E., Partyka, G., Pawson, S., Putman, W., Rienecker, M., Schubert, S. D., Sienkiewicz, M., and Zhao, B.: The Modern-Era Retrospective Analysis for Research and Applications, Version 2 (MERRA-2), J. Clim., 30, 5419-5454, 10.1175/JCLI-D-16-0758.1, 2017.

Gockede, M., Markkanen, T., Mauder, M., Arnold, K., Leps, J. P., and Foken, T.: Validation of footprint models using natural tracer measurements from a field experiment, Agric. For. Meteorol., 135, 314-325, 10.1016/j.agrformet.2005.12.008, 2005.

Gourdji, S. M., Mueller, K. L., Yadav, V., Huntzinger, D. N., Andrews, A. E., Trudeau, M., Petron, G., Nehrkorn, T., Eluszkiewicz, J., Henderson, J., Wen, D., Lin, J., Fischer, M., Sweeney, C., and Michalak, A. M.: North American $\mathrm{CO} 2$ exchange: inter-comparison of modeled estimates with results from a fine-scale atmospheric inversion, Biogeosciences, 9, 457-475, 10.5194/bg-9-457-2012, 2012.

Hinzman, L. D., Deal, C. J., McGuire, A. D., Mernild, S. H., Polyakov, I. V., and Walsh, J. E.: Trajectory of the Arctic as an integrated system, Ecol. Appl., 23, 1837-1868, 10.1890/11-1498.1, 2013.

Hu, L., Andrews, A. E., Thoning, K. W., Sweeney, C., Miller, J. B., Michalak, A. M., Dlugokencky, E., Tans, P. P., Shiga, Y. P., and Mountain, M.: Enhanced North American carbon uptake associated with El Niño, Science advances, 5 , eaaw0076, 2019.

Hugelius, G., Strauss, J., Zubrzycki, S., Harden, J. W., Schuur, E. A. G., Ping, C. L., Schirrmeister, L., Grosse, G., Michaelson, G. J., Koven, C. D., O'Donnell, J. A., Elberling, B., Mishra, U., Camill, P., Yu, Z., Palmtag, J., and Kuhry, P.: Estimated stocks of circumpolar permafrost carbon with quantified uncertainty ranges and identified data gaps, Biogeosciences, 11, 6573-6593, 10.5194/bg-11-6573-2014, 2014.

Janssens-Maenhout, G., Crippa, M., Guizzardi, D., Muntean, M., and Schaaf, E.: Emissions Database for Global Atmospheric Research, version v4.3.2 part I Greenhouse gases (time-series), in: Joint Research Centre (JRC), v4.3.2 ed., European Commission, 2017. 
Koven, C. D., Ringeval, B., Friedlingstein, P., Ciais, P., Cadule, P., Khvorostyanov, D., Krinner, G., and Tarnocai, C.: Permafrost carbon-climate feedbacks accelerate global warming, Proc. Natl. Acad. Sci. U. S. A., 108, 14769-14774, 10.1073/pnas.1103910108, 2011.

Lan, X., Tans, P., Sweeney, C., Andrews, A., Dlugokencky, E., Schwietzke, S., Kofler, J., McKain, K., Thoning, K., and Crotwell, M.: Long-Term Measurements Show Little Evidence for Large Increases in Total US Methane Emissions Over the Past Decade, Geophysical Research Letters, 46, 4991-4999, 2019.

Lauvaux, T., Schuh, A. E., Uliasz, M., Richardson, S., Miles, N., Andrews, A. E., Sweeney, C., Diaz, L. I., Martins, D., Shepson, P. B., and Davis, K. J.: Constraining the CO2 budget of the corn belt: exploring uncertainties from the assumptions in a mesoscale inverse system, Atmospheric Chemistry and Physics, 12, 337-354, 10.5194/acp-12337-2012, 2012.

Lawrence, D. M., Koven, C. D., Swenson, S. C., Riley, W. J., and Slater, A. G.: Permafrost thaw and resulting soil moisture changes regulate projected high-latitude $\mathrm{CO} 2$ and $\mathrm{CH} 4$ emissions, Environmental Research Letters, 10, 10.1088/1748-9326/10/9/094011, 2015.

McGuire, A. D., Koven, C., Lawrence, D. M., Clein, J. S., Xia, J., Beer, C., Burke, E., Chen, G., Chen, X., Delire, C., Jafarov, E., MacDougall, A. H., Marchenko, S., Nicolsky, D., Peng, S., Rinke, A., Saito, K., Zhang, W., Alkama, R., Bohn, T. J., Ciais, P., Decharme, B., Ekici, A., Gouttevin, I., Hajima, T., Hayes, D. J., Ji, D., Krinner, G., Lettenmaier, D. P., Luo, Y., Miller, P. A., Moore, J. C., Romanovsky, V., Schaedel, C., Schaefer, K., Schuur, E. A. G., Smith, B., Sueyoshi, T., and Zhuang, Q.: Variability in the sensitivity among model simulations of permafrost and carbon dynamics in the permafrost region between 1960 and 2009, Global Biogeochemical Cycles, 30, 1015-1037, 10.1002/2016gb005405, 2016.

Miller, C. E., Dinardo, S. J., Team, C. S., and Ieee: CARVE: The Carbon in Arctic Reservoirs Vulnerability Experiment, in: 2012 Ieee Aerospace Conference, IEEE Aerospace Conference Proceedings, Ieee, New York, 2012.

Miller, C. E., Griffith, P. C., Goetz, S. J., Hoy, E. E., Pinto, N., McCubbin, I. B., Thorpe, A. K., Hofton, M., Hodkinson, D., Hansen, C., Woods, J., Larson, E., Kasischke, E. S., and Margolis, H. A.: An overview of ABoVE airborne campaign data acquisitions and science opportunities, Environmental Research Letters, 14, 10.1088/17489326/ab0d44, 2019.

Molod, A., Takacs, L., Suarez, M., and Bacmeister, J.: Development of the GEOS-5 atmospheric general circulation model: evolution from MERRA to MERRA2, Geoscientific Model Development, 8, 1339-1356, 10.5194/gmd-8-13392015, 2015.

640 Mueller, K., Yadav, V., Lopez-Coto, I., Karion, A., Gourdji, S., Martin, C., and Whetstone, J.: Siting Background Towers to Characterize Incoming Air for Urban Greenhouse Gas Estimation: A Case Study in the Washington, DC/Baltimore Area, Journal of Geophysical Research-Atmospheres, 123, 2910-2926, 10.1002/2017jd027364, 2018.

Oda, T., and Maksyutov, S.: A very high-resolution (1 km x $1 \mathrm{~km}$ ) global fossil fuel CO2 emission inventory derived using a point source database and satellite observations of nighttime lights, Atmospheric Chemistry and Physics, 11, 543556, 10.5194/acp-11-543-2011, 2011.

Ott, L., Duncan, B., Pawson, S., Colarco, P., Chin, M., Randles, C., Diehl, T., and Nielsen, E.: Influence of the 2006 Indonesian biomass burning aerosols on tropical dynamics studied with the GEOS-5 AGCM, Journal of Geophysical Research: Atmospheres, 115, 10.1029/2009JD013181, 2010.

650 Ott, L. E., Pawson, S., Collatz, G. J., Gregg, W. W., Menemenlis, D., Brix, H., Rousseaux, C. S., Bowman, K. W., Liu, J., Eldering, A., Gunson, M. R., and Kawa, S. R.: Assessing the magnitude of $\mathrm{CO} 2$ flux uncertainty in atmospheric $\mathrm{CO} 2$ records using products from NASA's Carbon Monitoring Flux Pilot Project, Journal of Geophysical ResearchAtmospheres, 120, 734-765, 10.1002/2014jd022411, 2015.

Parazoo, N. C., Commane, R., Wofsy, S. C., Koven, C. D., Sweeney, C., Lawrence, D. M., Lindaas, J., Chang, R. Y. W., and Miller, C. E.: Detecting regional patterns of changing CO2 flux in Alaska, Proc. Natl. Acad. Sci. U. S. A., 113, 7733-7738, 10.1073/pnas.1601085113, 2016.

Peters, W., Jacobson, A., Sweeney, C., Andrews, A., Conway, T., Masarie, K., Miller, J. B., Bruhwiler, L., Petron, G., Hirsch, A., Worthy, D., Werf, G. v. d., Randerson, J. T., Wennberg, P., Krol, M., and Tan, P.: The atmospheric perspective of carbon-dioxide exchange across North America: CarbonTracker, Proceedings of the National Acedemy of Sciences of the United States of America (PNAS), 2007. 
Poulter, B., Ciais, P., Hodson, E., Lischke, H., Maignan, F., Plummer, S., and Zimmermann, N. E.: Plant functional type mapping for earth system models, Geoscientific Model Development, 4, 993-1010, 10.5194/gmd-4-993-2011, 2011.

Rienecker, M. M., Suarez, M. J., Gelaro, R., Todling, R., Bacmeister, J., Liu, E., Bosilovich, M. G., Schubert, S. D., Takacs, L., Kim, G.-K., Bloom, S., Chen, J., Collins, D., Conaty, A., Da Silva, A., Gu, W., Joiner, J., Koster, R. D., Lucchesi, R., Molod, A., Owens, T., Pawson, S., Pegion, P., Redder, C. R., Reichle, R., Robertson, F. R., Ruddick, A. G., Sienkiewicz, M., and Woollen, J.: MERRA: NASA's Modern-Era Retrospective Analysis for Research and Applications, J. Clim., 24, 3624-3648, 10.1175/jcli-d-11-00015.1, 2011.

Sasakawa, M., Machida, T., Tsuda, N., Arshinov, M., Davydov, D., Fofonov, A., and Krasnov, O.: Aircraft and tower measurements of $\mathrm{CO} 2$ concentration in the planetary boundary layer and the lower free troposphere over southern taiga in West Siberia: Long-term records from 2002 to 2011, Journal of Geophysical Research: Atmospheres, 118, 9489-9498, 10.1002/jgrd.50755, 2013.

Saunois, M., Stavert, A. R., Poulter, B., Bousquet, P., Canadell, J. G., Jackson, R. B., Raymond, P. A., Dlugokencky, E. J., Houweling, S., Patra, P. K., Ciais, P., Arora, V. K., Bastviken, D., Bergamaschi, P., Blake, D. R., Brailsford, G., Bruhwiler, L., Carlson, K. M., Carrol, M., Castaldi, S., Chandra, N., Crevoisier, C., Crill, P. M., Covey, K., Curry, C. L., Etiope, G., Frankenberg, C., Gedney, N., Hegglin, M. I., Höglund-Isaksson, L., Hugelius, G., Ishizawa, M., Ito, A., Janssens-Maenhout, G., Jensen, K. M., Joos, F., Kleinen, T., Krummel, P. B., Langenfelds, R. L., Laruelle, G. G., Liu, L., Machida, T., Maksyutov, S., McDonald, K. C., McNorton, J., Miller, P. A., Melton, J. R., Morino, I., Müller, J., Murgia-Flores, F., Naik, V., Niwa, Y., Noce, S., O'Doherty, S., Parker, R. J., Peng, C., Peng, S., Peters, G. P., Prigent, C., Prinn, R., Ramonet, M., Regnier, P., Riley, W. J., Rosentreter, J. A., Segers, A., Simpson, I. J., Shi, H., Smith, S. J., Steele, L. P., Thornton, B. F., Tian, H., Tohjima, Y., Tubiello, F. N., Tsuruta, A., Viovy, N., Voulgarakis, A., Weber, T. S., van Weele, M., van der Werf, G. R., Weiss, R. F., Worthy, D., Wunch, D., Yin, Y., Yoshida, Y., Zhang, W., Zhang, Z., Zhao, Y., Zheng, B., Zhu, Q., Zhu, Q., and Zhuang, Q.: The Global Methane Budget 2000-2017, Earth Syst. Sci. Data Discuss., 2019, 1-136, 10.5194/essd-2019-128, 2019.

Schaefer, K., Lantuit, H., Romanovsky, V. E., Schuur, E. A. G., and Witt, R.: The impact of the permafrost carbon feedback on global climate, Environmental Research Letters, 9, 10.1088/1748-9326/9/8/085003, 2014.

Schmid, H. P.: Footprint modeling for vegetation atmosphere exchange studies: a review and perspective, Agric. For. Meteorol., 113, 159-183, 10.1016/s0168-1923(02)00107-7, 2002.

Schneider von Deimling, T., Meinshausen, M., Levermann, A., Huber, V., Frieler, K., Lawrence, D. M., and Brovkin, V.: Estimating the near-surface permafrost-carbon feedback on global warming, Biogeosciences, 9, 649-665, 10.5194/bg-9-649-2012, 2012.

Schuur, E. A. G., McGuire, A. D., Schaedel, C., Grosse, G., Harden, J. W., Hayes, D. J., Hugelius, G., Koven, C. D., Kuhry, P., Lawrence, D. M., Natali, S. M., Olefeldt, D., Romanovsky, V. E., Schaefer, K., Turetsky, M. R., Treat, C. C., and Vonk, J. E.: Climate change and the permafrost carbon feedback, Nature, 520, 171-179, 10.1038/nature14338, 2015.

Strode, S. A., Liu, J., Lait, L., Commane, R., Daube, B., Wofsy, S., Conaty, A., Newman, P., and Prather, M.: Forecasting carbon monoxide on a global scale for the ATom-1 aircraft mission: insights from airborne and satellite observations and modeling, Atmos. Chem. Phys., 18, 10955-10971, 10.5194/acp-18-10955-2018, 2018.

Sweeney, C., Karion, A., Wolter, S., Newberger, T., Guenther, D., Higgs, J. A., Andrews, A. E., Lang, P. M., Neff, D., Dlugokencky, E., Miller, J. B., Montzka, S. A., Miller, B. R., Masarie, K. A., Biraud, S. C., Novelli, P. C., Crotwell, M., Crotwell, A. M., Thoning, K., and Tans, P. P.: Seasonal climatology of CO2 across North America from aircraft measurements in the NOAA/ESRL Global Greenhouse Gas Reference Network, Journal of Geophysical ResearchAtmospheres, 120, 5155-5190, 10.1002/2014jd022591, 2015.

Sweeney, C., Dlugokencky, E., Miller, C. E., Wofsy, S., Karion, A., Dinardo, S., Chang, R. Y. W., Miller, J. B., Bruhwiler, L., Crotwell, A. M., Newberger, T., McKain, K., Stone, R. S., Wolter, S. E., Lang, P. E., and Tans, P.: No significant increase in long-term $\mathrm{CH} 4$ emissions on North Slope of Alaska despite significant increase in air temperature, Geophysical Research Letters, 43, 6604-6611, 10.1002/2016gl069292, 2016.

Sweeney, C., and McKain, K.: ABoVE: Atmospheric Profiles of CO, CO2 and CH4 Concentrations from Arctic-CAP, 2017, in, ORNL Distributed Active Archive Center, 2019. 
Sweeney, C., McKain, K., Miller, B. R., and Michel, S. E.: ABoVE: Atmospheric Gas Concentrations from Airborne Flasks, Arctic-CAP, 2017, in, ORNL Distributed Active Archive Center, 2020.

Takahashi, T., Sutherland, S. C., Wanninkhof, R., Sweeney, C., Feely, R. A., Chipman, D. W., Hales, B., Friederich, G., Chavez, F., Sabine, C., Watson, A., Bakker, D. C. E., Schuster, U., Metzl, N., Yoshikawa-Inoue, H., Ishii, M., Midorikawa, T., Nojiri, Y., Kortzinger, A., Steinhoff, T., Hoppema, M., Olafsson, J., Arnarson, T. S., Tilbrook, B., Johannessen, T., Olsen, A., Bellerby, R., Wong, C. S., Delille, B., Bates, N. R., and de Baar, H. J. W.: Climatological mean and decadal change in surface ocean $\mathrm{pCO}(2)$, and net sea-air CO2 flux over the global oceans, Deep-Sea Res. Part II-Top. Stud. Oceanogr., 56, 554-577, 10.1016/j.dsr2.2008.12.009, 2009.

Thompson, R. L., Sasakawa, M., Machida, T., Aalto, T., Worthy, D., Lavric, J. V., Myhre, C. L., and Stohl, A.: Methane fluxes in the high northern latitudes for 2005-2013 estimated using a Bayesian atmospheric inversion, Atmospheric Chemistry and Physics, 17, 3553-3572, 10.5194/acp-17-3553-2017, 2017.

Van Der Werf, G. R., Randerson, J. T., Collatz, G. J., and Giglio, L.: Carbon emissions from fires in tropical and subtropical ecosystems, Glob. Change Biol., 9, 547-562, 10.1046/j.1365-2486.2003.00604.x, 2003.

Wania, R., Ross, I., and Prentice, I. C.: Integrating peatlands and permafrost into a dynamic global vegetation model: 1. Evaluation and sensitivity of physical land surface processes, Global Biogeochemical Cycles, 23, 10.1029/2008gb003412, 2009.

Weir, B., Ott, L., Collatz, G., Kawa, S. R., Poulter, B., Chatterjee, A., Oda, T., and Pawson, S.: Calibrating satellite-derived surface carbon fluxes for reanalyses and near real-time monitoring systems, Atmospheric Chemistry and Physics. , In review, 2020.

Welp, L. R., Patra, P. K., Rödenbeck, C., Nemani, R., Bi, J., Piper, S. C., and Keeling, R. F.: Increasing summer net CO2 uptake in high northern ecosystems inferred from atmospheric inversions and comparisons to remote-sensing NDVI, Atmos. Chem. Phys., 16, 9047-9066, 10.5194/acp-16-9047-2016, 2016.

Wofsy, S. C., Afshar, S., Allen, H. M., Apel, E., Asher, E. C., Barletta, B., Bent, J., Bian, H., Biggs, B. C., Blake, D. R., Blake, N., Bourgeois, I., Brock, C. A., Brune, W. H., Budney, J. W., Bui, T. P., Butler, A., Campuzano-Jost, P., Chang, C. S., Chin, M., Commane, R., Correa, G., Crounse, J. D., Cullis, P. D., Daube, B. C., Day, D. A., DeanDay, J. M., Dibb, J. E., Digangi, J. P., Diskin, G. S., Dollner, M., Elkins, J. W., Erdesz, F., Fiore, A. M., Flynn, C. M., Froyd, K., Gesler, D. W., Hall, S. R., Hanisco, T. F., Hannun, R. A., Hills, A. J., Hintsa, E. J., Hoffman, A., Hornbrook, R. S., Huey, L. G., Hughes, S., Jimenez, J. L., Johnson, B. J., Katich, J. M., Keeling, R., Kim, M. J., Kupc, A., Lait, L. R., Lamarque, J. F., Liu, J., McKain, K., McLaughlin, R. J., Meinardi, S., Miller, D. O., Montzka, S. A., Moore, F. L., Morgan, E. J., Murphy, D. M., Murray, L. T., Nault, B. A., Neuman, J. A., Newman, P. A., Nicely, J. M., Pan, X., Paplawsky, W., Peischl, J., Prather, M. J., Price, D. J., Ray, E., Reeves, J. M., Richardson, M., Rollins, A. W., Rosenlof, K. H., Ryerson, T. B., Scheuer, E., Schill, G. P., Schroder, J. C., Schwarz, J. P., St.Clair, J. M., Steenrod, S. D., Stephens, B. B., Strode, S. A., Sweeney, C., Tanner, D., Teng, A. P., Thames, A. B., Thompson, C. R., Ullmann, K., Veres, P. R., Vizenor, N., Wagner, N. L., Watt, A., Weber, R., Weinzierl, B., Wennberg, P., Williamson, C. J., Wilson, J. C., Wolfe, G. M., Woods, C. T., and Zeng, L. H.: ATom: Merged Atmospheric Chemistry, Trace Gases, and Aerosols, in, ORNL Distributed Active Archive Center, 2018.

Wunch, D., Wennberg, P. O., Messerschmidt, J., Parazoo, N. C., Toon, G. C., Deutscher, N. M., Keppel-Aleks, G., Roehl, C. M., Randerson, J. T., Warneke, T., and Notholt, J.: The covariation of Northern Hemisphere summertime $\mathrm{CO}<$ sub $>2</$ sub $>$ with surface temperature in boreal regions, Atmos. Chem. Phys., 13, 9447-9459, 10.5194/acp13-9447-2013, 2013.

750 Zhang, Z., Zimmermann, N. E., Kaplan, J. O., and Poulter, B.: Modeling spatiotemporal dynamics of global wetlands: comprehensive evaluation of a new sub-grid TOPMODEL parameterization and uncertainties, Biogeosciences, 13, 1387-1408, 10.5194/bg-13-1387-2016, 2016. 


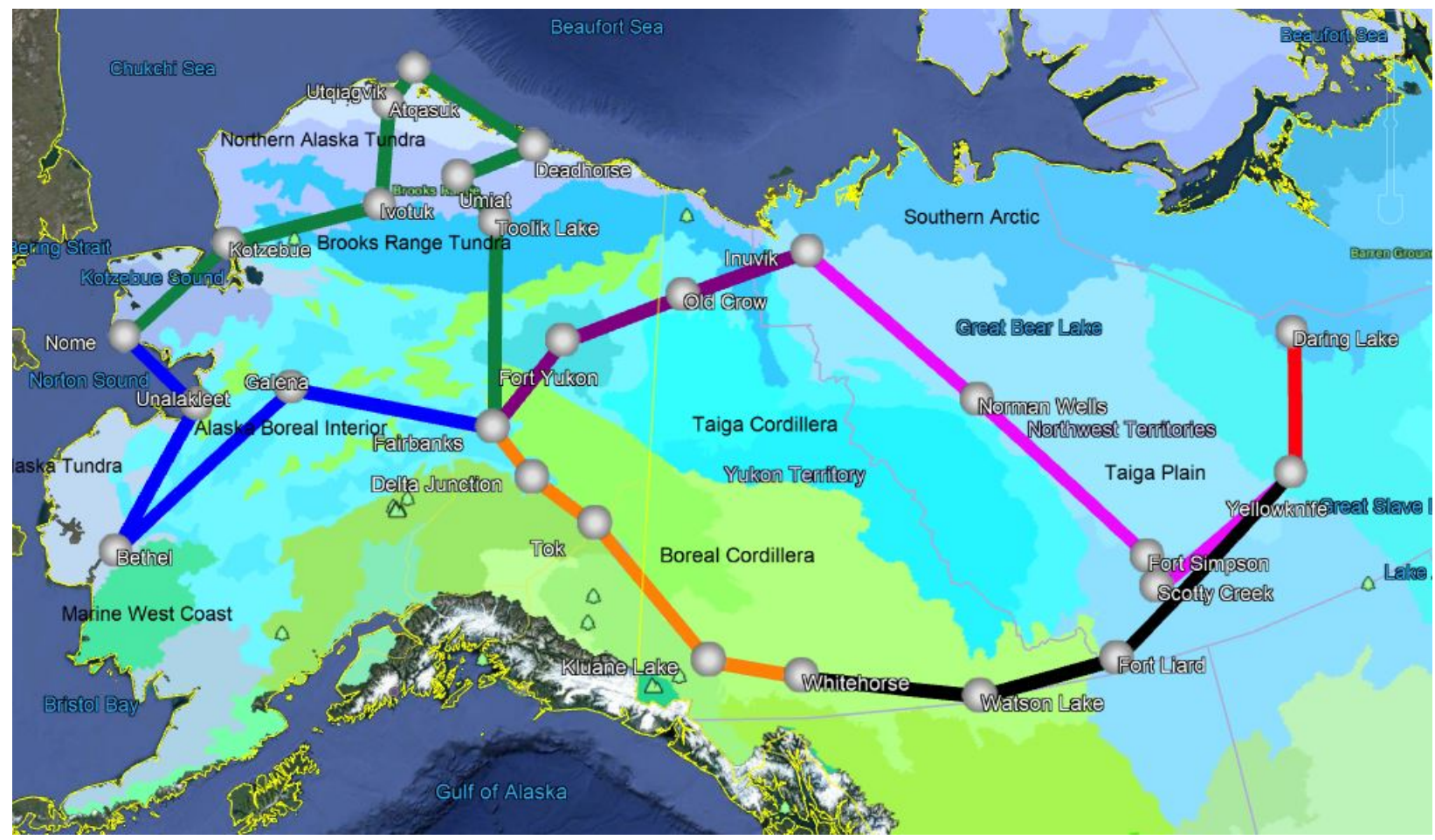

Figure. 1. The Arctic-CAP surveys were designed to sample the Arctic boreal ecosystems of the $\mathrm{ABoVE}$ domain. Black text labels represent the six ecoregions covered by this study and white text denote cities and states / provinces. Gray dots depict the locations on which the Arctic-CAP vertical profiles were centered (C Google Earth). 


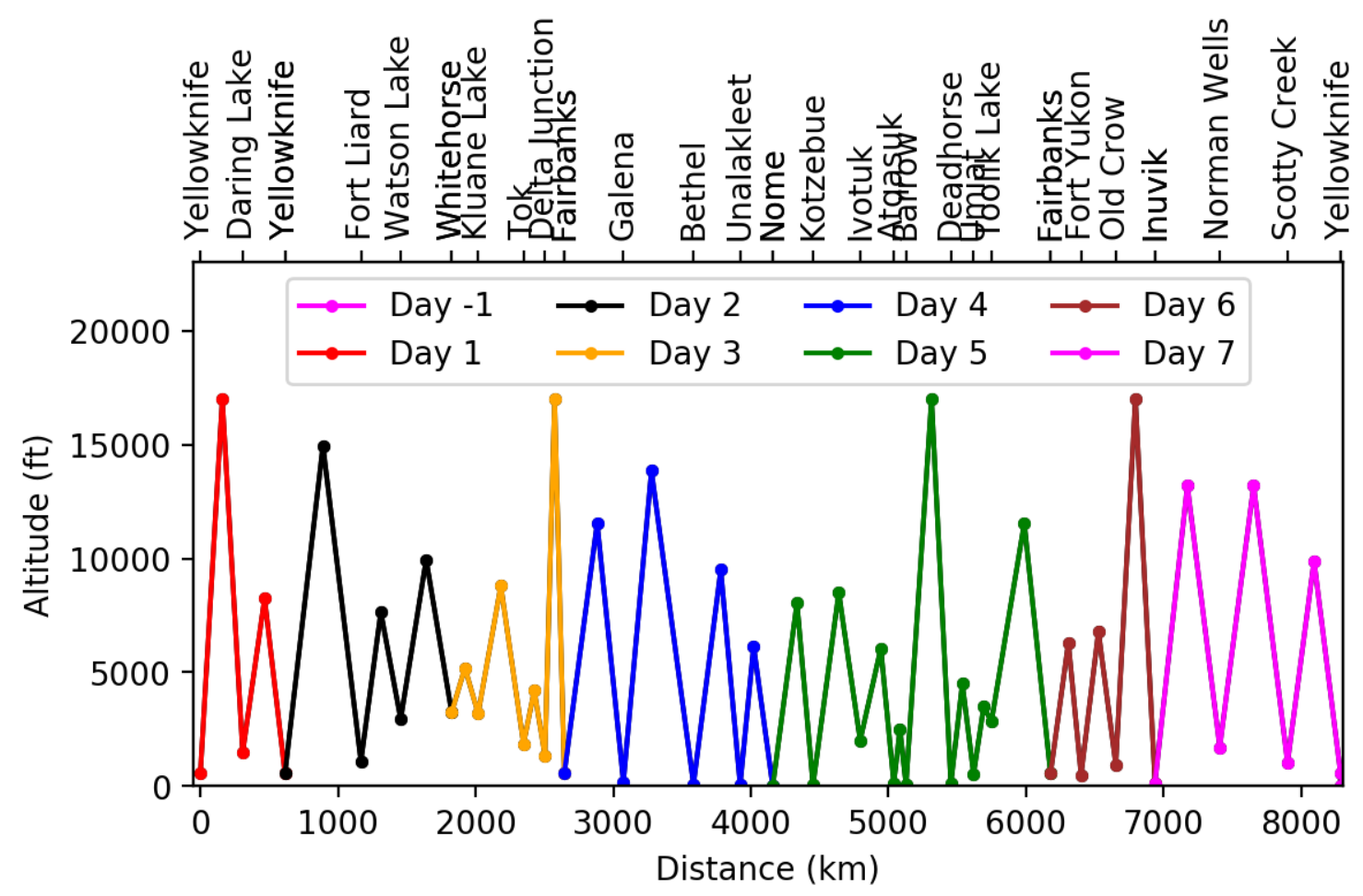

Figure. 2. Locations and maximum altitudes of the 25 vertical profiles that were acquired during each Arctic-CAP campaign. The colors match the flight lines illustrated in Fig. 1.

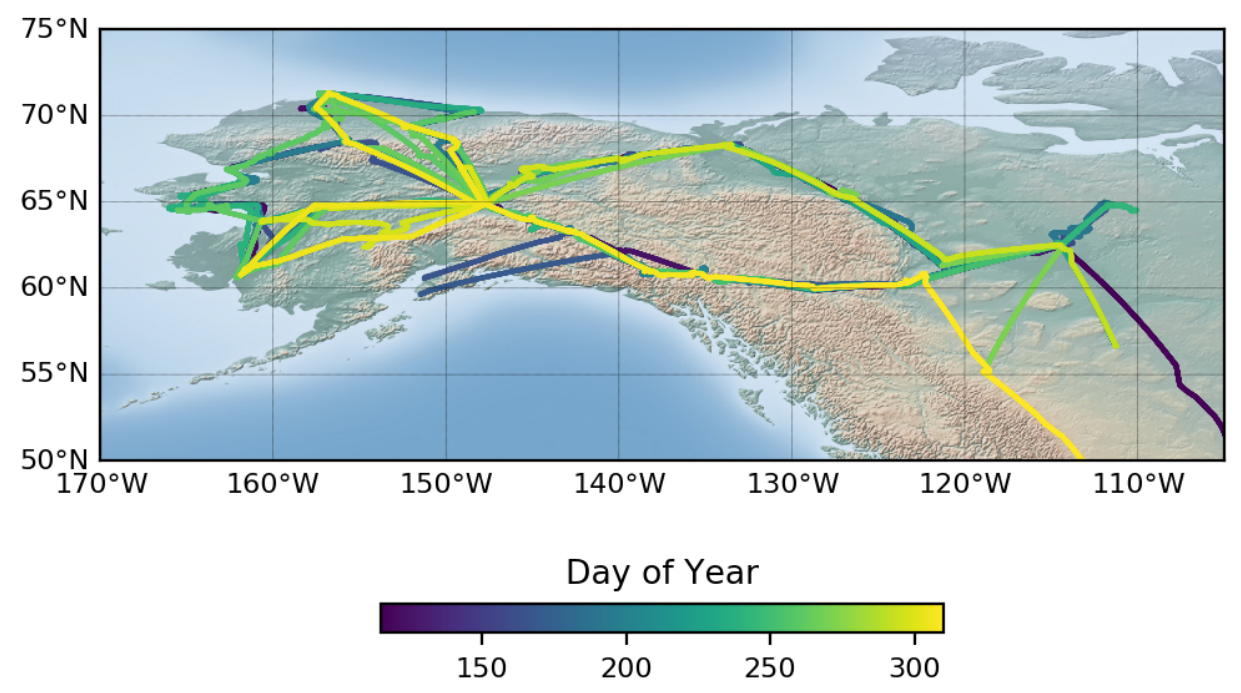

Figure 3 Arctic-CAP flight paths colored by day of year (DOY). Later paths are plotted on top, masking flights from earlier in the year along the same routes. Profile locations span 50-75 ${ }^{\circ} \mathrm{N}$ and $105-165^{\circ} \mathrm{W}$ and sampled environmental conditions from the spring thaw ( DOY 125) through the early cold season (> DOY 300) (C Google Maps). 
https://doi.org/10.5194/acp-2020-609

Preprint. Discussion started: 11 September 2020

(c) Author(s) 2020. CC BY 4.0 License.
Atmospheric

Chemistry

and Physics

Discussions
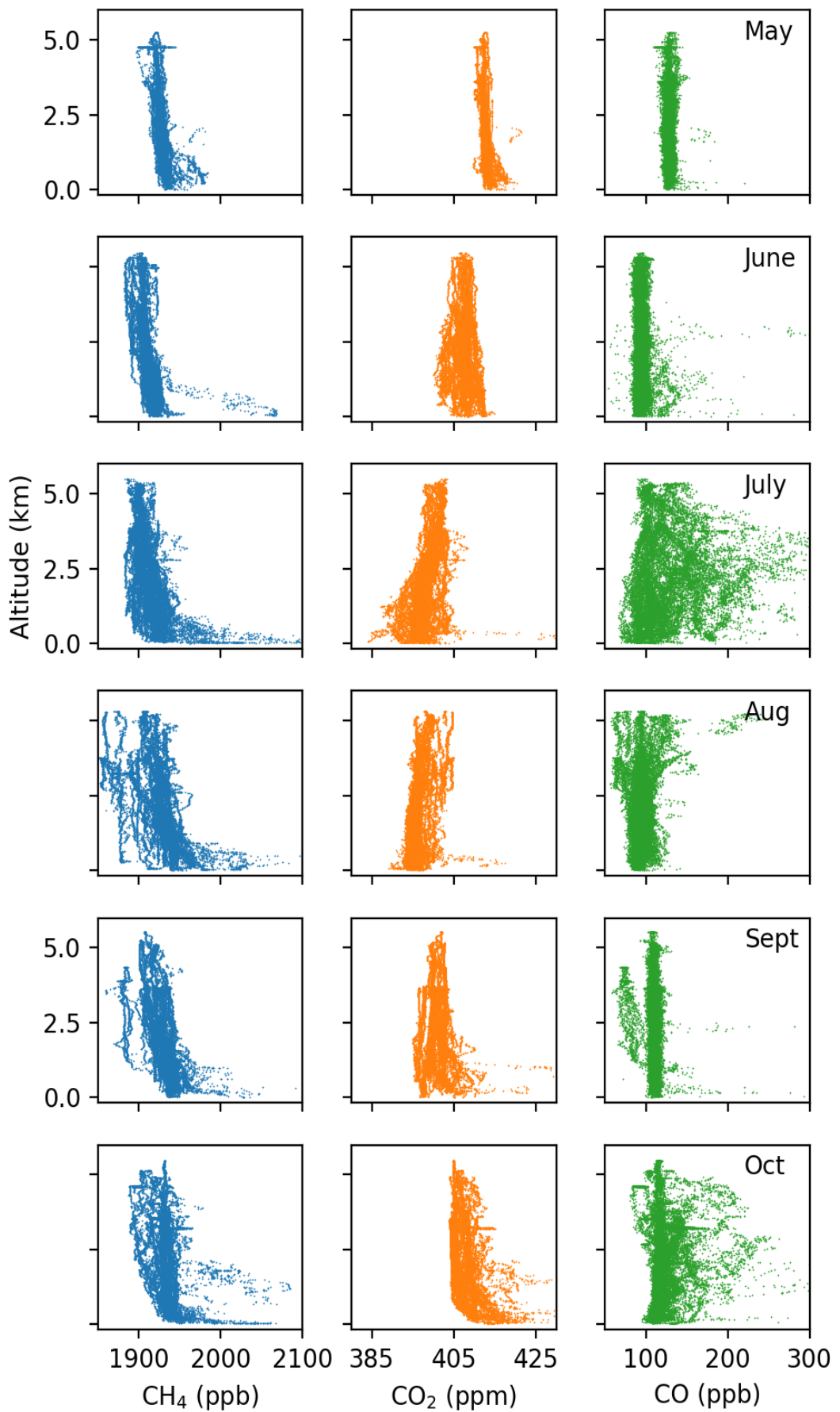

$\mathrm{CH}_{4}(\mathrm{ppb})$

$\mathrm{CO}_{2}(\mathrm{ppm})$

Figure 4. Composite plots of the $\mathrm{CH}_{4}$ (left column), $\mathrm{CO}_{2}$ (center column) and $\mathrm{CO}$ (right column) measurements acquired during the Arctic-CAP airborne campaign in 2017. 


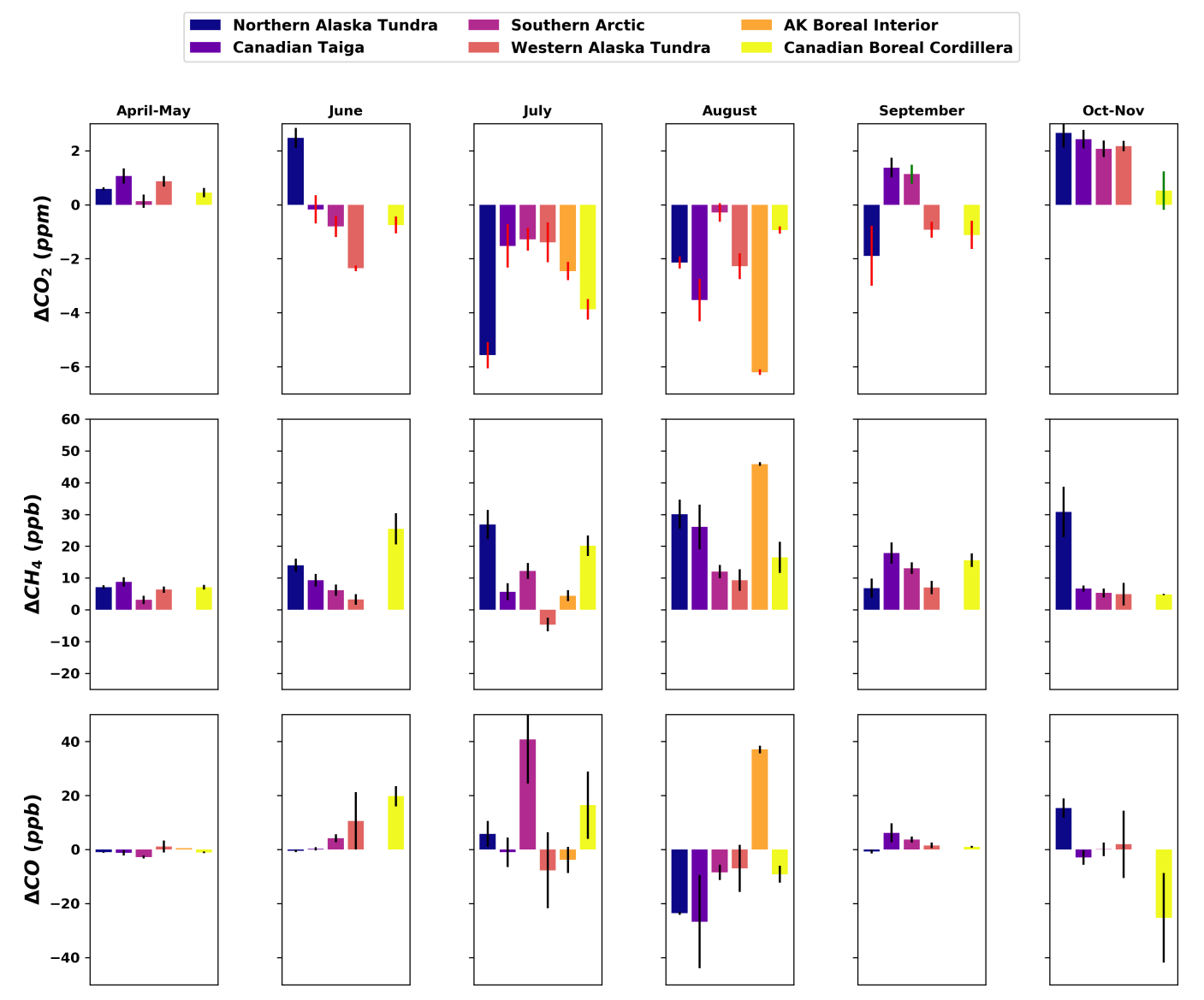

775 Figure 5. Average gradient between the mean free daily troposphere ( $>3000$ masl for $\mathrm{CO}_{2}$ and $\mathrm{CH}_{4}$ and 4000 masl for CO) and measurements made below 3000 masl during each campaign. Colors refer to the six ecoregions identified in Fig. 1. 

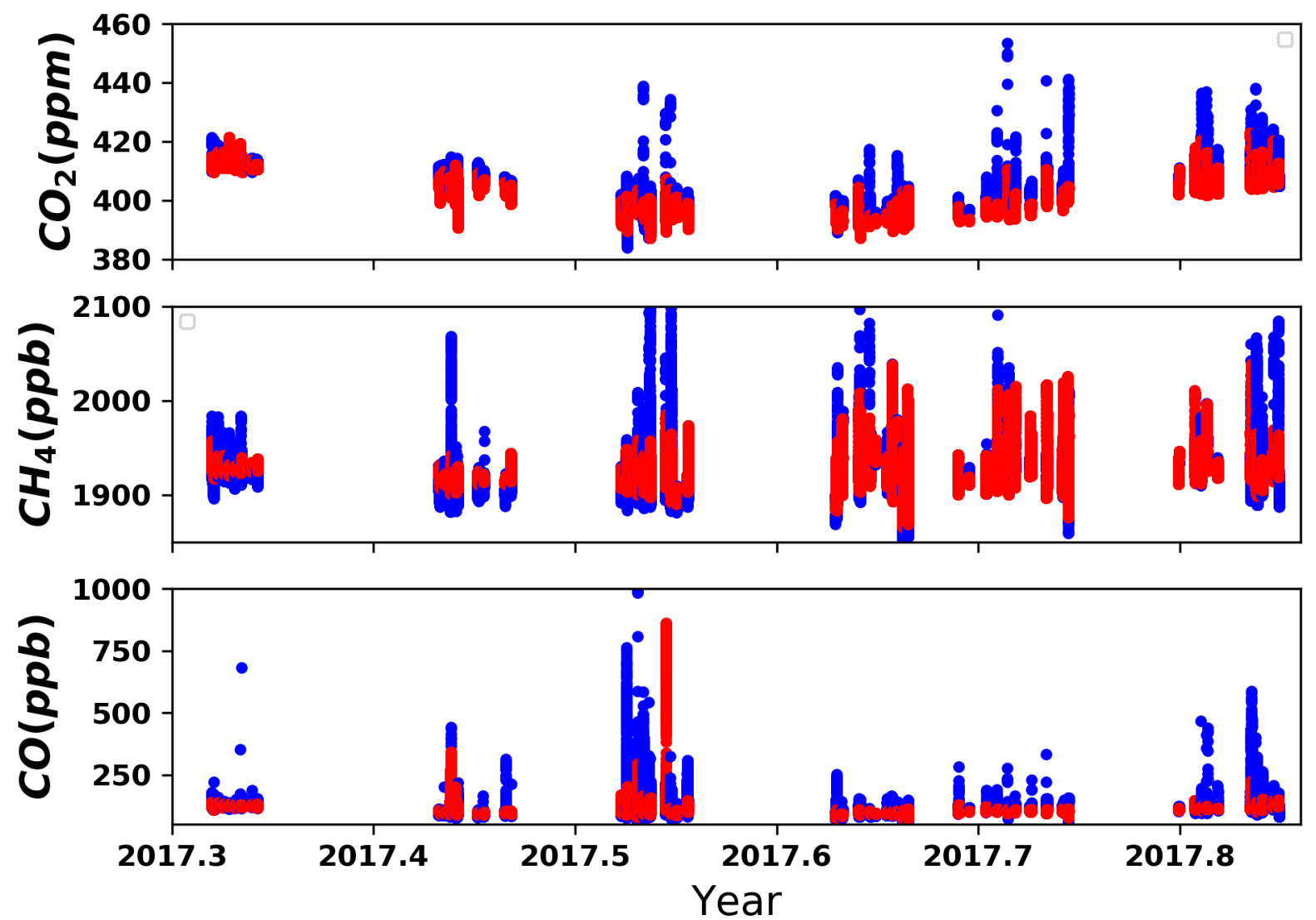

Figure 6. Comparisons of GEOS simulated atmospheric $\mathrm{CO}_{2}, \mathrm{CH}_{4}$ and $\mathrm{CO}$ (red points) versus observed $\mathrm{CO}_{2}, \mathrm{CH}_{4}$ and CO (blue points) during the Arctic-CAP 2017 campaign show good agreement across campaigns, although the observed data exhibit larger extremes. 


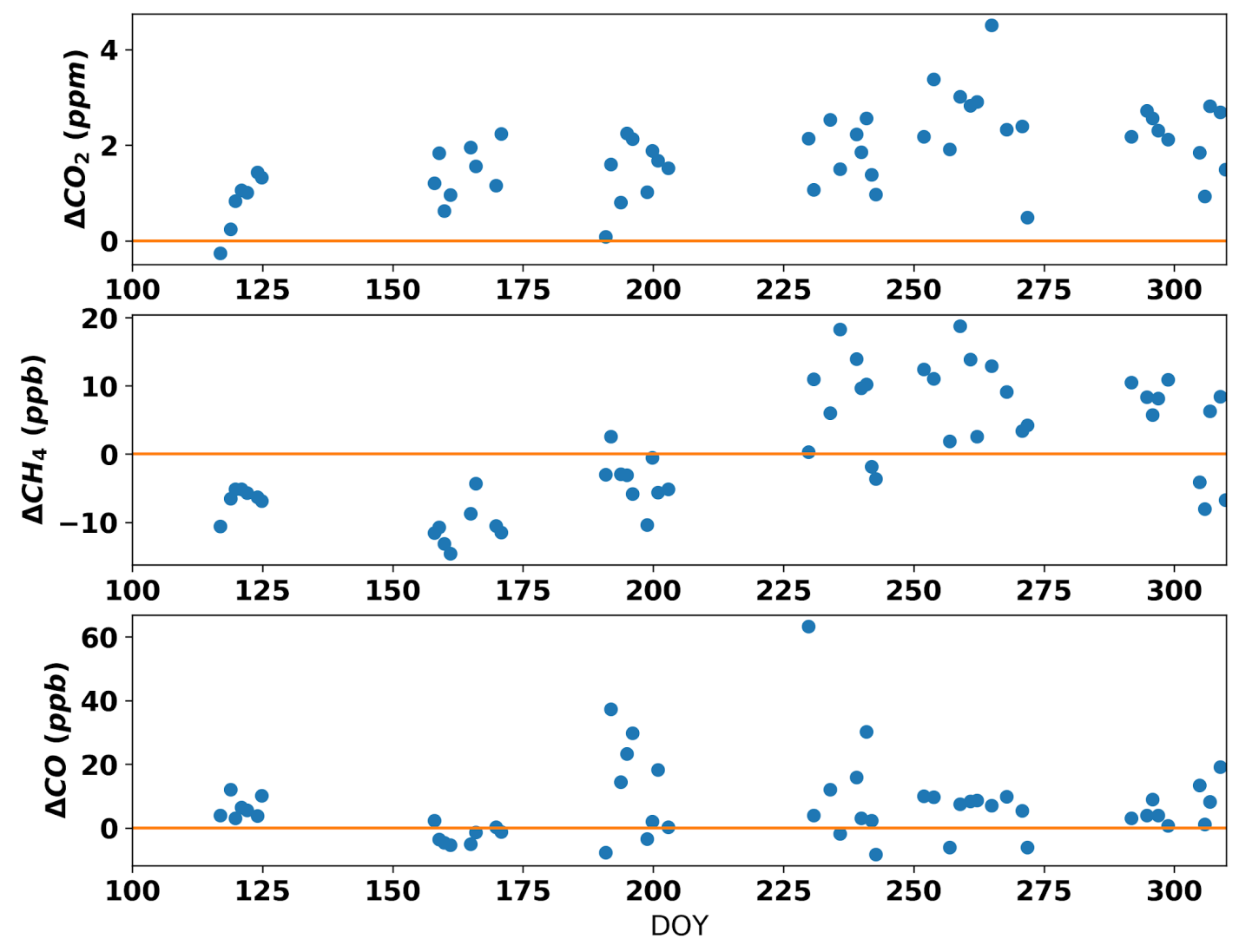

Figure 7. Difference (observations-model) between mean daily free troposphere (3000-5000 masl for $\mathrm{CO}_{2}$ and $\mathrm{CH}_{4}$ and 785 4000-5000 masl for CO) for GEOS simulated and Arctic-CAP observed mole fractions. The GEOS simulations systematically underestimate the mean $\mathrm{CO}_{2}$ in all months, while the model overestimates $\mathrm{CH}_{4}$ before DOY 200 and underestimates $\mathrm{CH}_{4}$ after DOY 200. Simulated CO observations generally agree with the atmospheric observations, although there are sporadic underestimates likely associated with incorrectly modeled fire plumes. 
https://doi.org/10.5194/acp-2020-609

Preprint. Discussion started: 11 September 2020

(c) Author(s) 2020. CC BY 4.0 License.

(c) (i)

790
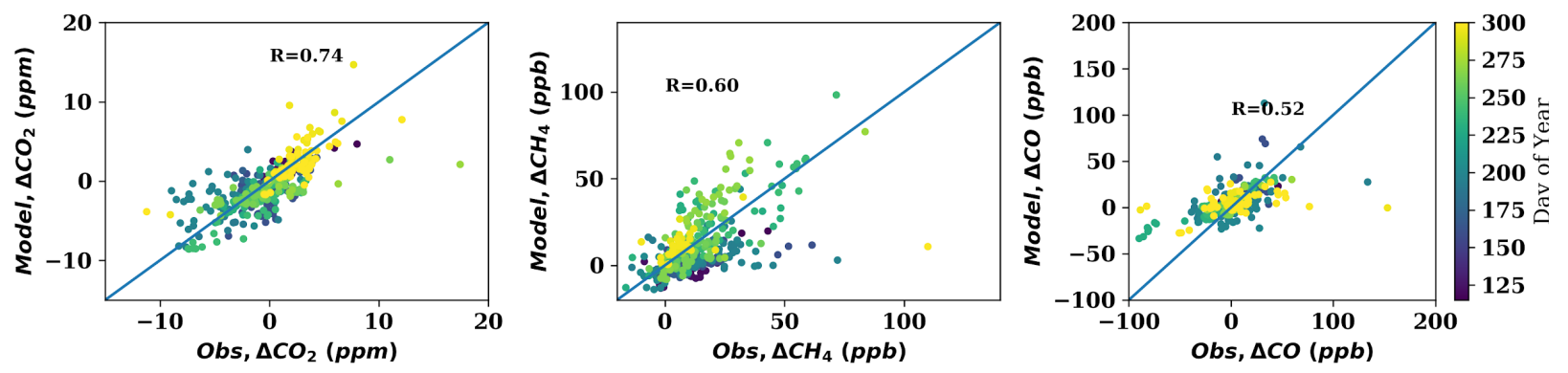

Figure 8. Modeled versus observed average boundary layer enhancements or depletions in $\mathrm{CO}_{2}, \mathrm{CH}_{4}$ and $\mathrm{CO}$ for individual profiles from $\mathbf{3 0 0 0}$ masl down to the surface level. 

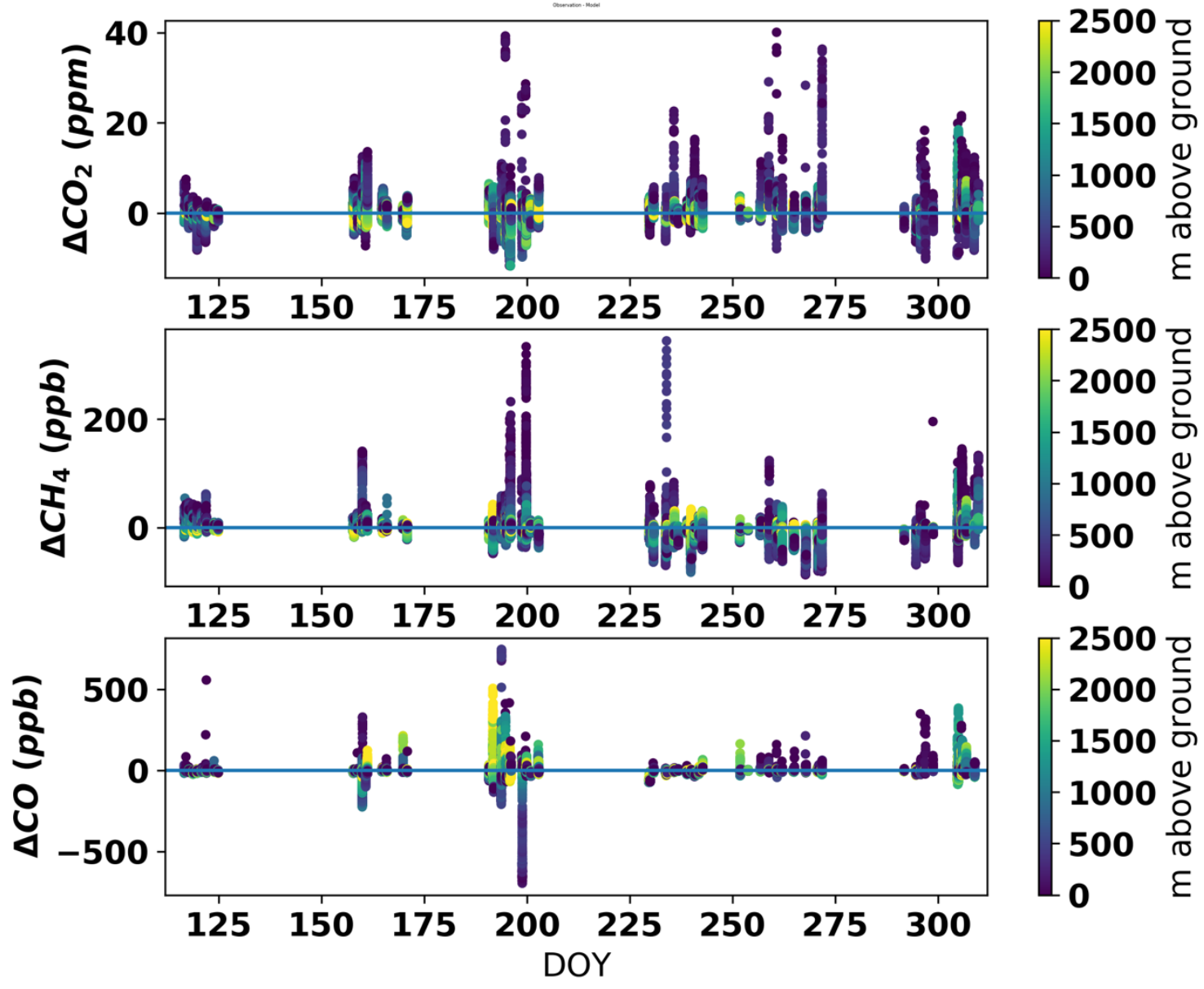

Figure 9. Observation-model differences in mole fractions below 3000 masl. Corrections have been made for observation-model offsets above 3000 masl (Fig. 7). Colors show the altitude of each deviation. Dark blue indicates differences near the surface while yellow indicates differences near 3000 masl. 

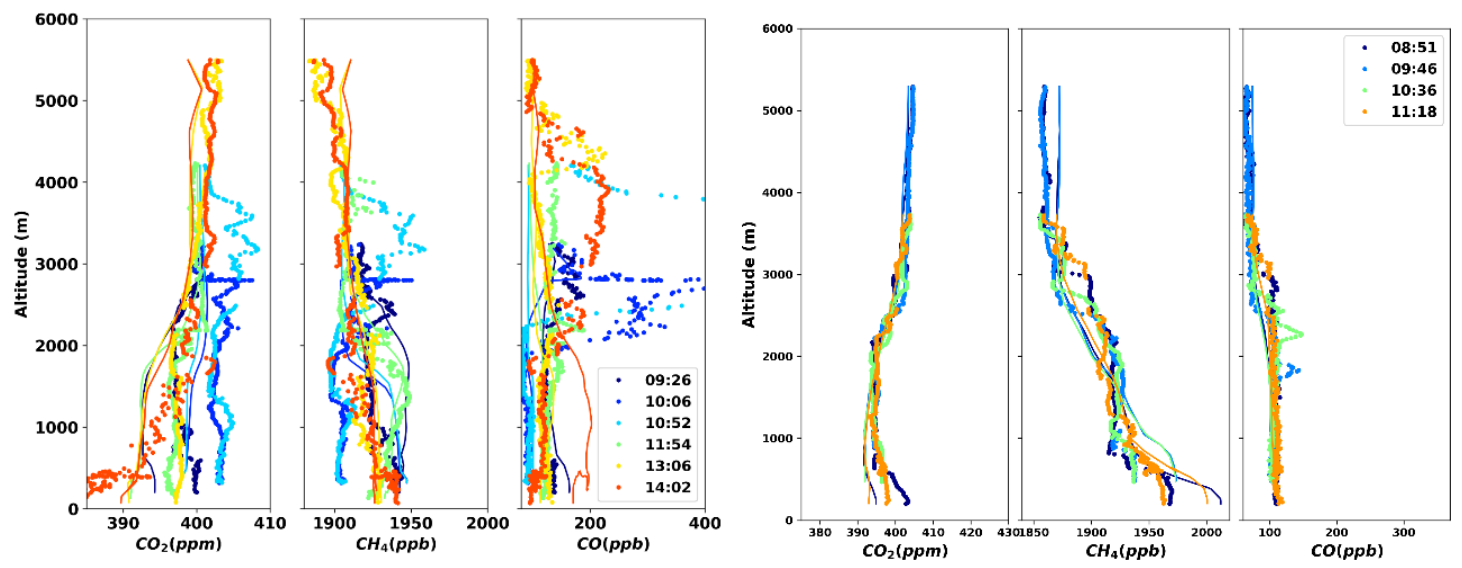

Figure 10. Observation (dotted lines) and model estimates (thin lines) of profiles on July 10, 2017 (left) and August 30, 2017 (right) from a transect up the Mackenzie River in the Northwest Territory of Canada. Dotted lines show observations and thin lines show model estimates corresponding to specific times during the transect. 


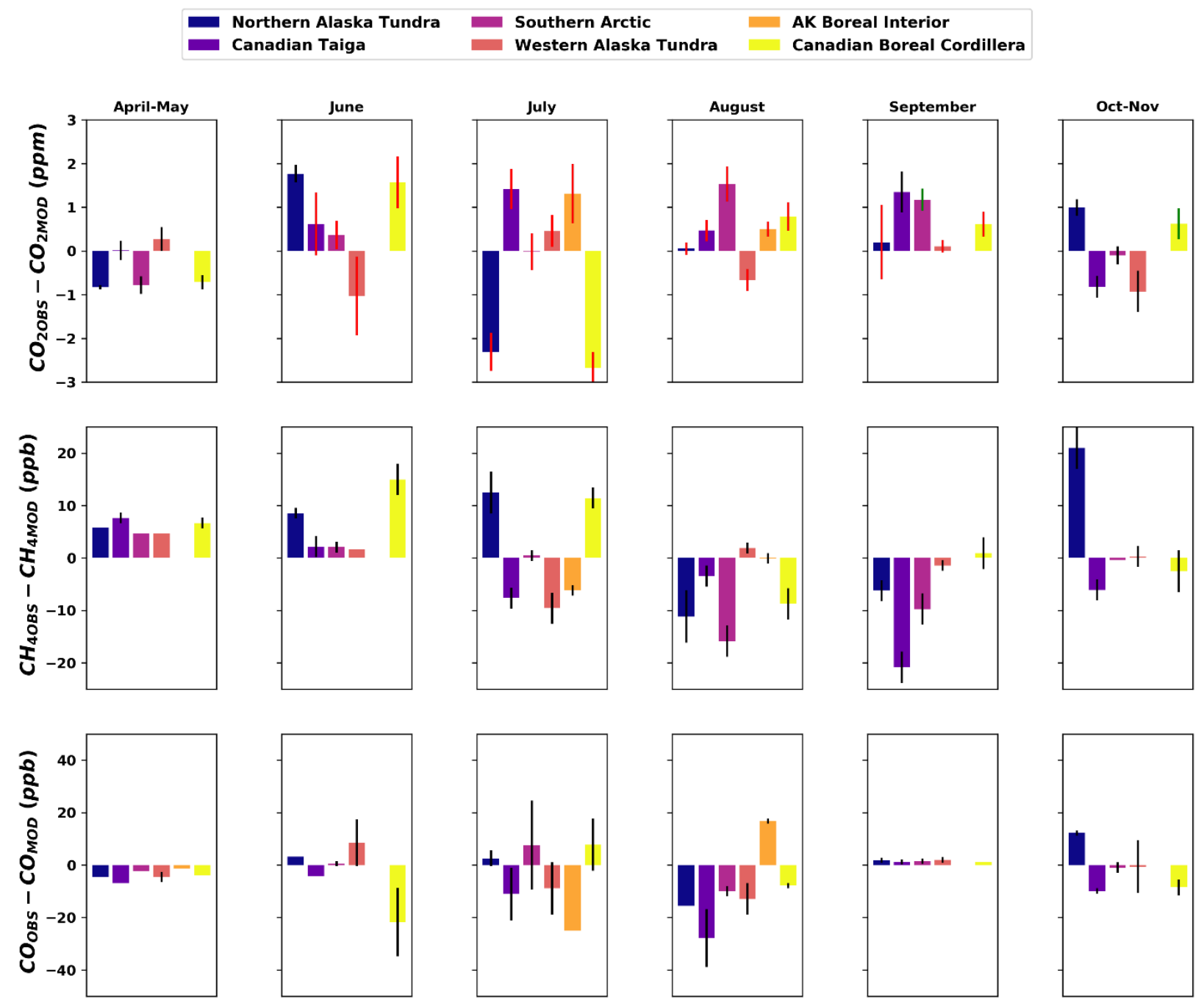

805 Figure 11. Average observation-model integrated enhancement differences by ecoregion. Standard deviation of differences for each region are shown with black and red bars. Red (black) bars signify a negative (positive) average enhancement below 3000 meters relative to the daily mean tropospheric value above 3000 masl for $\mathrm{CO}_{2}$ and $\mathrm{CH}_{4}$ and above 4000 masl for $\mathrm{CO}$. 